\title{
BUILDING TECHNICAL CAPITAL AMONG COMMUNITY COLLEGE STUDENTS IN ADVANCED TECHNOLOGICAL EDUCATION
}

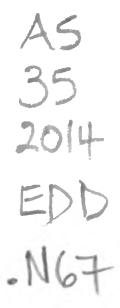

Doctor of Education

In

Educational Leadership

by

Armineh Noravian

San Francisco, California

May 2014 
Copyright by

Armineh Noravian

2014 


\section{CERTIFICATION OF APPROVAL}

I certify that I have read Building Technical Capital Among Community College Students in Advanced Technological Education by Armineh Noravian, and that in my opinion this work meets the criteria for approving a dissertation submitted in partial fulfillment of the requirement for the degree: Doctor of Education in Educational Leadership at San Francisco State University.

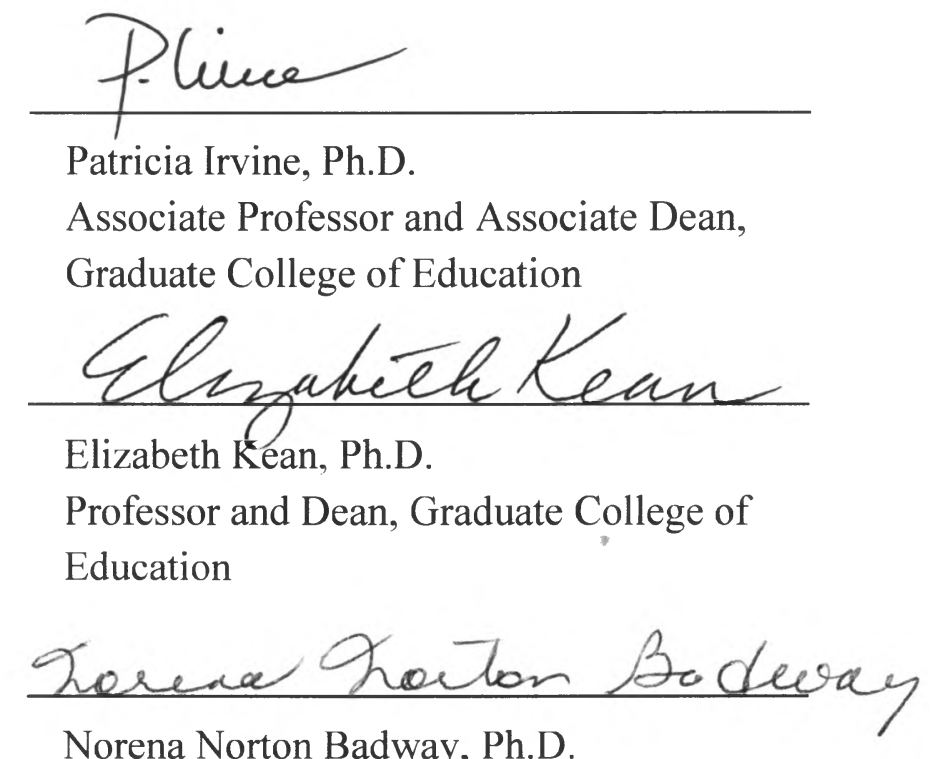

Norena Norton Badway, Ph.D.

Ed. D. Educational Leadership Program

Coordinator 


\section{TABLE OF CONTENTS}

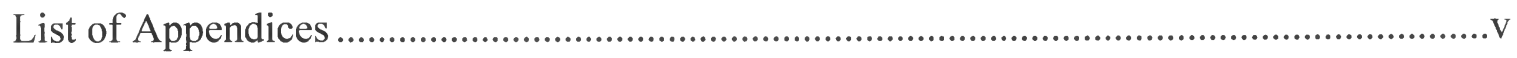

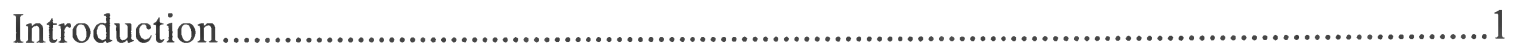

Paper 1 Community College Student Perspectives on Project-Based Learning...................9

Paper 2 Acquiring Professional Identities in Project-Based Learning in a Community

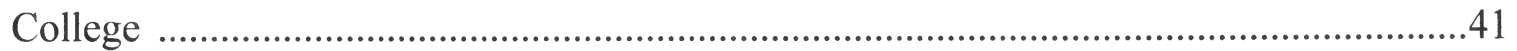

Paper 3 How Do Well-Structured Problems Influence the Identities of Technology Students in Community College?

Appendices 105 


\section{LIST OF APPENDICES}

$\begin{array}{lll}\text { Appendix } & \text { Page }\end{array}$

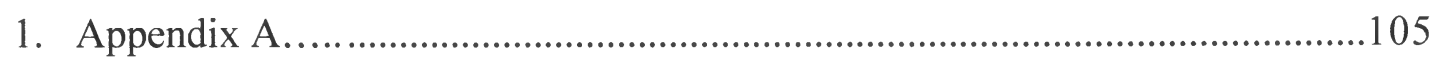

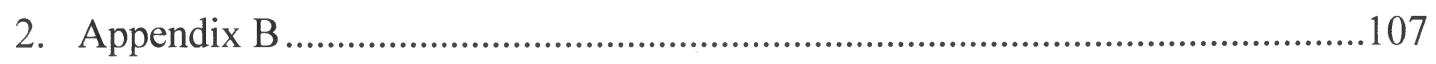




\section{Introduction}

Women, ethnic/racial minorities, and individuals from low socioeconomic background continue to be underrepresented and marginalized in science, technology, engineering, and mathematics (STEM) fields. This study investigates steps taken by programs funded by National Science Foundation Advanced Technological Education (NSF-ATE) to change this inequity. Thus, the main research question is the following: What is the role of problem-oriented pedagogical strategies in affecting professional identities among community college students in advanced technological education? This research is composed of three distinct but related research studies regarding the introduction of well- and ill-structured problems into advanced technological education (ATE). Well-structured problems, for the purposes of this paper, are defined as educational exercises to which a limited number and variety of rules and principles might be applied, within set parameters, with pre-determined right or wrong solutions (Jonassen, 2012). Ill-structured problems, on the other hand, use learning activities which might have numerous solutions and pathways to solutions, have few parameters, and which contain uncertainty or ambiguity about how they are organized and which solutions might be justified (Jonassen, 2012). Both types of activities can be described as "hands-on" or "authentic", but the well-structured problem-oriented pedagogy is based on information processing theory whereas loosely-structured pedagogy is grounded in constructivism and situated cognition theories of learning (Bransford, Brown, \& Cocking, 2000). 


\section{Research Questions and Links across Papers 1, 2, and 3}

The three papers in this collection approach authentic pedagogical strategies from different, but related, perspectives. Paper 1, Community College Student Perspectives on Project-Based Learning, explores community college student perspectives on illstructured projects (Jonassen, 1997) in an ATE program. While there is a good deal of literature about the cognitive benefits of such projects (Blumenfeld et al., 1991), there is scant evidence of the social-emotional impact on students. Paper 1 examines the perspectives of students who experienced ill-structured problems in a technical education program at Southeastern Community College (SCC). The findings indicate that (1) students experienced a change in their sense of who they were and what they could accomplish academically and professionally through having experienced ill-structured projects and (2) learning through ill-structured projects is an approach that allows diverse community college students seeking a technician education an equitable means of achieving college success. These findings have implications for expanding access and success in technician and engineering education. I submitted paper 1 to the Journal of Engineering Education and I have received feedback (see appendix A). I have revised and resubmitted paper 1 to the same journal.

Paper 2, Acquiring Professional Identities in Project-Based Learning in a Community College, identifies the positive impact of ill-structured problems (Jonassen, 1997) on the professional identities of underprepared students and students from low socioeconomic backgrounds. Paper 1 revealed that students experienced a change in their 
sense of who they were and what they could accomplish academically and professionally by working on ill-structured problems (Jonassen, 1997). Paper 2 builds on this finding by investigating if specific PBL processes can be connected with changes in students' professional identities.. The findings indicate that the students' experiences in illstructured projects allow them to acquire a technician identity, which increases their confidence. Moreover, their experience provides them the self-esteem to continue their education and to pursue new ambitions, such as moving up the ladder in their organizations. The success of participants indicates that PBL may be a promising practice that can help build the self-esteem of underrepresented students, including students of color and students from low socioeconomic backgrounds, first-generation students, students who may have had negative educational experiences in the past and people who have become unemployed. Moreover, it indicates that this process can cater to a diverse student body in terms of ages, work and educational background. I submitted paper 2 to the Interdisciplinary Journal of Problem-Based Learning and I have received feedback (see appendix B). Paper 2 in this dissertation reflects some of the changes requested by the journal reviewers.

Without a comparison studies of well-structured problem-oriented learning (Jonassen, 1997) it would not be possible to understand whether the change in students' identities is a unique characteristic of ill-structured projects or whether well-structured problems also influence student identities in a similar manner. Without this knowledge pedagogic or policy recommendations could not be made. Moreover, ill-structured 
projects require faculty sophistication and professional development that instructors may not be able to obtain due to scant resources in community colleges. Thus, paper 3 , How Do Well-Structured Projects Influence the Identities of Technology Students in Community College? focuses on an ATE program in a North West Community College (NWCC) that uses well-structured problem-oriented learning (Jonassen, 1997) to determine whether projects that reside on the well-structured end of the continuum offer the possibility of developing students' professional identities as technicians. The findings indicate that students working on well-structured problems develop technician identities when they perceive that what they are learning is what technicians would be expected to know in the workplace. This finding does not agree with Jonassen's (2000) claim that well-structured problems do not provide adequate preparation for graduates to function in professional contexts. Moreover, in contrast to Jonassen, projects that begin as wellstructured and become less well-structured could be effective in developing students' knowledge and experience so that they can successfully tackle technically sophisticated and more ill-structured problems. Paper 3 was submitted to the Journal of Technology Education.

\section{Summary of Findings}

Two key concepts have emerged as a result of this study that have consequences for pedagogy and curriculum design. One of these concepts is the professional identities as technicians that students in both well- and ill-structured problems developed and the other is the concept of technical capital. 
First, as noted previously, identities are meanings that define what it means to be who one is in a role (Burke \& Tully, 1977; Goffman, 1959). The meaning of a technician identity in this study has become defined as being a student in a community college technician education who becomes technically knowledgeable and able to competently and with confidence apply that knowledge to solve a technical problem, as would be expected of a technician in a job. Regardless of whether the students were engaged in solving well- or ill-structured problems (Jonassen, 2012), if they perceived that they were learning content that helped them build the skills that they needed to become technicians or were performing tasks that they would be required to perform as technicians, they were able to develop a professional identity as technicians. Developing a professional identity in community college for a job that requires an associate's degree may help students overcome the hurdles associated with being first in their family to seek such jobs. In other words, for students who are first generation college students or low-income students this process is likely to build the kind of cultural capital (Bourdieu, 1977) that they might need to succeed.

Second, a central construct in this study is technical capital, which is experience with "tinkering," manipulating tools, doing hands-on work, and knowing the process of solving problems that require technical solutions. Community college students may not only lack a college going background but also lack technical capital before they enter college. The findings of this study indicate students' perception of what they learn and how they make sense of what they learn is linked to their personal histories - their prior 
knowledge of how things work (Macaulay \& Ardley, 1998). When students do not have a prior history with working with their hands or dealing with ill-structured projects, scaffolding experiences - moving from very well structured problems to ill-structured problems - allows students who lack technical capital to gain content knowledge and experience to deal with ill-structured and technically sophisticated problems. Without such support, students who are underrepresented in technical fields may be unable to see themselves fit into the culture of technicians and engineers and less likely to make sense of their experiences as meaningful or useful in building a professional identity and therefore less likely to succeed in technician or pre-baccalaureate engineering education.

The findings reported in these three papers have implications for expanding access and success in technician and engineering education to students of diverse backgrounds who attend community colleges. First, students' experiences in ill-structured projects increases their self-esteem, allows them to develop a technician identity, helps them persevere in community college, and boosts their confidence as students and technicians. Moreover, students who perform well-structured projects that they perceive they need to become technicians also allows them to develop a professional identity as technicians. Second, instructors should not choose between well- and ill- structured problems. Rather, curriculum design should focus on scaffolding from well-structured to less well-structured and then to ill-structured problems. Third, students' perspectives provide the data needed to investigate the effectiveness and the impact of pedagogical 
practices on students' self-esteem and identity. These perspectives could help improve teaching and learning for community college students underrepresented in STEM.

\section{References}

Baillie, C., Pawley, A. L., \& Riley, D. (Eds.). (2011). Engineering and Social Justice: In the University and Beyond. Purdue University Press.

Blumenfeld, P. C., Soloway, E., Marx, R. W., Krajcik, J. S., Guzdial, M., \& Palincsar, A. (1991). Motivating project-based learning: Sustaining the doing, supporting the learning. Educational Psychologist, 26(3 \& 4), 369-398.

Bourdieu, P. (1977). Cultural reproduction and social reproduction. In J. Karabel \& A. H. Halsey (Eds.), Power and ideology in education (pp. 487-510). New York: Oxford University Press, Inc.

Bransford, J., Brown, A. L., \& Cocking, R. (2000). How people learn: Brain, mind, experience, and school. Washington, D.C.: National Academy Press.

Burke, P. J., \& Tully, J. C. (1977). The measurement of role identity. Social Forces, $55(4), 881-897$.

Goffman, E. (1959). The presentation of the self in everyday life. New York: Anchor Books.

Hakimzadeh, H., Adaikkalavan, R., \& Wolfer, J. (2011). CS0: A project based, active learning course. International Transaction Journal of Engineering, Management, \& Applied Sciences \& Technologies, 2(5), 493-506. 
Jonassen, D. H. (1997). Instructional design models for well-structured and ill-Structured problem-solving learning outcomes. Educational Technology Research and Development, 45(1), 65-94.

Jonassen, D. H. (2000). Toward a design theory of problem solving. Educational Technology Research and Development, 48(4), 63-85.

Jonassen, D. H. (2012). Designing for decision making. Educational Technology Research Development, 60(2), 341-359.

King, C. J. (2012). Restructuring engineering education: Why, how and when? Journal of Engineering Education, 101(1), 1-5.

Lehmann, M., Christensen, P., Du, X., \& Thrane, M. (2008). Problem-oriented and project-based learning (POPBL) as an innovative learning strategy for sustainable development in engineering education. European ,Journal of Engineering Education, 33(3), 283-295. doi:10.1080/03043790802088566

Macaulay, D., \& Ardley, N. (1998). The new way things work. Boston: Houghton Mifflin Company. 


\title{
Paper 1
}

\section{Community College Student Perspectives on Project-Based Learning}

\begin{abstract}
Background: Project-based learning (PBL) as a teaching tool in introductory engineering classes or technician training in community colleges may be one way to increase the breath of engineering undergraduate education and to make engineering education more attractive and accessible to underrepresented populations.

Purpose: This exploratory study examines the perspectives of students who experienced ill-structured problems in their PBL classrooms in a technical education program at Southeastern Community College (SCC) to understand how these students perceive their experiences and to learn whether students believe these experiences are helping them reach their college and career goals.

Methodology: Data for this qualitative study was collected by interviewing eight community college students in a rural community county in the Southeastern part of the United States. The participants were 50\% African Americans and 50\% Caucasian. Results: The findings indicate that students interpreted their project experiences based on their personal histories and their social interactions with their team members. The PBL classroom was a safe space for learning and their experiences changed the way they felt about themselves.
\end{abstract}

Conclusions: The findings indicate that PBL appears to provide a teaching approach that allows diverse community college students from low socioeconomic backgrounds 
seeking a technician education an equitable means of achieving college success. These findings have implications for expanding access and success in technician and engineering education.

\section{Introduction}

Although there is scholarly literature on applying pedagogies that use illstructured problems in engineering and technology at universities (Hakimzadeh, Adaikkalavan, \& Wolfer, 2011; Lehmann, Christensen, Du, \& Thrane, 2008), little attention has been specifically given to community college students in technological education programs. Research to obtain the perspective of community college students in project-based learning (PBL) using ill-structured problem (Jonassen, 2000) in technical education is important to understand whether these experiences are helping students reach their career and educational goals.

Technical education is highly relevant to engineering education; over forty percent of all four-year engineering graduates have enrolled in community colleges (Baillie, Pawley, \& Riley, 2011), in which they receive their introductory engineering education. In a recent editorial, King (2012) argued that since the engineering degree is entirely concentrated in an undergraduate bachelor's degree, there is little room for "much needed breadth" (King, 2012, p. 1) in engineering education. He further argued that the rigorous quantitative focus of undergraduate engineering education make it unattractive to a diverse population. King (2012) asserted that engineering education in the United States needs to evolve so that American engineers can master more than 
engineering concepts; they need other kinds of knowledge to compete globally and to be able to function effectively working with other cultures and societies all over the globe. As this study shows, PBL may be a way to meet King's demands. As a pedagogical tool in introductory engineering classes or engineering technician training in community colleges, it may be one way to increase both the breath of engineering undergraduate education and to make engineering education more attractive and accessible to underrepresented populations.

This exploratory study examines the perspectives of students who experienced illstructured problems in their PBL classrooms in a technical education program at Southeastern Community College (SCC) to understand how these students perceive their experiences and to learn whether students believe these experiences are helping them reach their college and career goals. The study is significant because student perspectives contribute to a better understanding of (1) how diverse community college students work together to navigate their way through project-based learning in a technical education classroom and (2) ways to help community college students meet career and educational goals.

This research was conducted in conjunction with a larger study "From Pipeline to Pathways: Entering, Completing and Returning to STEM Career Pathways Through ATE" funded by the National Science Foundation (NSF). While the goal of the larger study is to find promising Advanced Technological Education (ATE) programs and 
practices, the scope of this particular study is focused only on the experiences of technical education students in their PBL classroom.

\section{Theoretical Framework}

In this study, symbolic interactionism is used as an analytic tool to gain a contextualized understanding of student perspectives about PBL. Symbolic interactionism is grounded in three principles (Aksan, Kisac, \& Demirbuken, 2009; Blumer, 1986). First, people act towards all phenomena based on the meanings they hold for them. This principle emphasizes contextual rather than absolute meanings of actions, activities, and symbols for each individual. For example, a tool that an electronics technology student uses in his projects class at the community college will have a specific meaning if he has already used that tool in his workplace. It is likely that he will feel comfortable in using the tool in a manner that he has used before. Secondly, understandings are formed in the context of social interactions. This second principle suggests that individuals develop meanings for things they encounter through interacting with others in their environment. For instance, it is likely that the electronics technology student will learn a different use of his tool if he sees his project team members successfully using the tool in a manner that he had not seen before. Thirdly, these meanings change through an individual's interpretation of the experiences in which he participates. That is, people use their knowledge to interpret their experiences and then act in a manner that is meaningful to them (Spradley, 1979). In sum, a student interprets the meaning of objects, situations, and other symbols (1) in the context of the situation in 
which the student is placed, (2) based on a student's individual characteristics and interactions with others, and (3) these meanings are then used and revised to guide her/his actions in any situation.

Using symbolic interactionism as a framework allows us to interpret students' interactions with others and their perspectives as they participate in PBL in technology education classes at the community college.

\section{Literature Review}

\section{Project-Based Learning}

The term project-based learning (PBL) is often used in popular and research literature in a variety of ways. In this study, PBL is used to mean an active pedagogy that engages students in projects where they are required to solve ill-structured problems (Jonassen, 2012). A problem is defined as an unknown in a situation (Jonassen, 2000) and ill-structured problems are encountered in everyday and technological practice and lack predictable solutions (Jonassen, 2012). Ill-structured problems require that students integrate multiple disciplines and search beyond what they have previously learned in coursework. Meacham and Emont (1989) have noted that ill-structured problems compel students to come to conclusions based partly on personal opinion or beliefs, creating a space for human social and relational activities. At SCC, students were engaged in solving ill-structured problems in their PBL classes. In this study, because there are so many different types of PBL, the model of PBL that is embraced is simply projects in which students had to solve ill-structured problems. 
Very few studies explore the consequences of PBL-based technology programs on student learning in post-secondary institutions. This section describes studies that do exist, showing their focus on four-year institutions and not community colleges.

PBL allows students to realize that complex real life problems require interdisciplinary knowledge and the integration of both technical and non-technical solutions. Lehmann, Christensen, Du, and Thrane (2008) examined sustainability engineering students in a master's degree program at Aalborg University, Denmark that incorporated problem-oriented and project-based learning (POPBL). Danish students and students from other parts of the world who had different engineering and science undergraduate degrees worked together in groups with companies or organizations outside the university. Lehman et al. (2008) concluded that the POPBL approach to sustainability engineering allowed students to solve real-world problems in an interdisciplinary and context-based environment. While the current study shows that community college PBL offers the same benefits to students, the Lehmann et al. (2008) study was conducted with master's degree candidates at a four-year institution.

Introductory courses that are based on PBL can be used to offer four-year college students a nontraditional entry into an engineering program. Frank, Lavy, and Elata (2003) studied the effect of a PBL-based introductory course for freshmen mechanical engineering students at Technion, an institution located in Haifa, Israel. Students worked in small groups on various projects constructing devices that would perform certain tasks. Frank et al. (2003), based on their qualitative analysis of semi-structured interviews of 
students on their perspectives on their experiences, indicated that students reported having developed engineering-style thinking, an increased motivation to study, a collaborative learning style, and personal and interpersonal skills. The current study interviewed community college students and showed many of the same outcomes, including a willingness to continue their education at either two-year or four-year institutions.

PBL can be used to improve retention among students at a four-year institution that are considered at risk. Hakimzadeh, Adaikkalavan, and Wolfer (2011) studied a PBL-based introductory computer science course designed to improve retention among students considered at risk at Indiana University South Bend. Students worked on realworld problems in small groups. Hakimzadeh et al. (2011) concluded that students' motivation, attendance levels, and levels of retention was higher when compared to students in a traditional entry-level computer science course. In contrast, the current study focuses on the retention consequences of a PBL-based technology program on student learning in a community college.

The participants in the current study differ from other studies in higher education in that they all come from low socioeconomic backgrounds. Socioeconomic status is emerging as another important variable in diversity in engineering (Strutz, Orr, \& Ohland, 2012). Students from such backgrounds attend high schools that are not equipped to provide them adequate pre-engineering academic content in math and science and do not help them develop basic study skills, such as organization and learning strategies 
needed for success (McLoughlin, 2012). Moreover, there is a mismatch between the lives of these students and the expectations of engineering curricula in a four-year institution: "Engineering education has largely been structured around an elite student body, so nontraditional students who need to work or have family obligations seldom choose engineering" (McLoughlin, 2012, p. 124). Thus, community colleges provide students from low socioeconomic backgrounds an opportunity to enter engineering education through their dedication to open admissions and serve students whose academic preparation would not have provided them admission directly into a 4-year engineering program (McLoughlin, 2012). The students in this study are such students. As the findings indicate, the participants who experienced PBL in SCC in a technical education program were able to build their skills and confidence while in a supportive environment to the point that they saw entering a 4-year college as a possibility.

\section{Community College Student Characteristics}

Students attend community college for a number of reasons (Malcom, 2013). The cost of attending a 2-year institution is well below that of a 4-year institution. In addition, the close proximity to students' home also allows students to live at home while attending college, further reducing the financial burden. In 2010, of the 7.5 million students who were enrolled in two-year colleges, $57 \%$ were independent students who came from families with a yearly income less than $\$ 36,000$ (Malcom, 2013). Moreover, community colleges offer part-time courses which enable students to work, study, and take care of their families. Community college students are likely to have dependent children or 
families, be older than 24, and have to balance work, family, and school (Bailey \& Morest, 2006). Data from 2010 also indicated that $56 \%$ of the attendees were part-time (National Center for Education Statistics, 2011). In addition, community colleges are able to respond to industry needs by offering programs that prepare students for currently available jobs. Students needing to obtain employment quickly to support themselves and/or their families are able to obtain skills in a short time frame through access to industry jobs that require more than just a high school diploma (Malcom, 2013).

Low income students and students of color are most likely not to complete any degree at the community college. Of the students who drop out of community college, $60 \%$ or more are low income students or students of color (Bailey \& Morest, 2006; Hoachlander, Sikora, \& Horn, 2003). In 2010, 58\% of the students in community colleges were women (National Center for Education Statistics, 2011), 40\% were racial/ethnic minorities, nearly 38\% were first-generation college students (Malcom, 2013).Thus, even though many low income students and students of color are provided access to community colleges, their low levels of completion indicate that studies are needed to understand how to help retain such students in STEM. The participants in this study were drawn from community college technical education courses using PBL.

\section{Methodology}

This study explores community college student perspectives on PBL in a technical education program at a 2-year college to understand how these students 
perceive their experiences and to explore whether these experiences are helping them reach their college and career goals.

A social constructivism (Creswell, 2009; Prawat, 1996) epistemological view guided this study of eight community college students and graduates enrolled in technician education. Because a constructivist approach assumes that people's perceptions are relative and that reality is socially constructed (McDavid \& Hawthorn, 2006), I have used the perspectives from these eight participants to provide insight about how they perceived their experiences and whether these experiences helped them reach their college and career goals. Since symbolic interactionist constructivists study how and why participants construct meanings and actions in specific ways (Charmaz, 2011; Silverman, 2011), I have tried to interpret participants experiences to suggest an explanation of how and why they experienced what they did in their various ill-structured projects in PBL classrooms. The interviews were thus designed to elicit the experiences of the students, their interpretation of their experiences, how they used these interpretations to give meaning to and influence their interactions with others in their classes, and how they used these to reach current educational goals. This type of data could only be adequately captured by a qualitative research approach (Blumer, 1986; Bogdan \& Biklen, 2006; Spradley, 1979). The unit of analysis throughout the study is the student and/or the graduate from the community college.

Constructivists also acknowledge that their own background shapes their interpretation, which is influenced by "their own personal, cultural, and historical 
experiences" (Creswell, 2009, p. 8). As an engineer, I find the descriptions of the experiences of the participants to be similar to mine. I relate to their experiences perhaps more than I would have had I not been a practicing engineer. I also know that their stories as students involved in technology are not necessarily heard. People involved in technology are often referred to as "geeks," a term that disparagingly refer to people who lack social grace and are single-mindedly interested in technology. By giving voice to the perspective of these students and their struggles, I hope to show the personal side of these "geeks." This is important for me as a female as the experiences of these participants may change the perception that engineering education is not for women.

I conducted eight face-to-face interviews with technology students at SCC engaged in PBL classes. The interview protocol included open-ended questions about the student experiences in a PBL course. Each interview took approximately one hour and was conducted either at SCC or a local coffee shop. The student interactions were captured from interview data in which students described their experiences, interactions, and perceptions of themselves as students in their PBL classrooms. I analyzed the data using symbolic interactionism as a framework.

The selection of participants was done based on selective and purposeful sampling (Coyne, 1997). Students had been pre-selected for the interview based on information provided in the larger study to reflect diversity in age, race, background, sex, and program of study. The purpose behind this sampling technique was to interview 
individuals who could provide "information-rich" data (Coyne, 1997, p. 624) about their learning experiences.

This study does not attempt to provide "truths" (Silverman, 2011, p. 37) about technology education students' perceptions of PBL in community college in general, but rather hopes to raise awareness about how students perceive their experiences in illstructured project-based learning classrooms. Thus, this study can be seen as "exploratory rather than definitive," (Silverman, 2011, p. 37) examining the perspectives of individuals in a specific setting so as to open additional investigative possibilities (Silverman, 2011).

Since the purpose of this paper is to explicate the students' perspectives on their experiences, their own words are used liberally in reporting the identified themes. Students' quotes are followed by my own interpretation in an attempt to show how the themes emerged from the data.

\section{Participants}

The interviewees were diverse in age, ranging from 18 to 55 years old. The participants were similar in that they were all males and lived in the rural area near the community college. Regardless of whether participants were employed but wanted to move up the ladder within their organization or they were unemployed and needed a job, this program provided them the opportunity to acquire the skills and knowledge to meet

their goals. These participants represented the typical community college student populations: They mostly came from working-class families and were the first in the 
immediate family to attend college. Fifty percent of the participants were African American while the other $50 \%$ were White.

\section{Results}

\section{Themes}

Symbolic interactionist constructivism allows analysis at individual, social, and subjective levels. Blumer (1986) argues that individuals have autonomy and in social interactions they do not just internalize socially constructed meanings. Instead, they think about and communicate internally what they are experiencing socially. However, in this framework, the social world is the prime source of meanings as individuals try to make sense of their world. In other words, meanings are a social product that come about in the process of interaction between people, but individuals have a certain level of autonomy and participate in the development of common meaning (Blumer, 1986; Prawat, 1996).

Various themes that reflect individual, social, and subjective levels of analysis emerged in the analysis of the data. To see how participants interpreted their project experiences on an individual level, data that indicated interpretations of experiences based on individuals' past or present experiences and history gave rise to the theme "influence of personal history." The social level of analysis involved two parts: (a) Data that captured participants' interpretations of their project experiences through interactions with their team members provided the first part of the social level of analysis and is discussed in the theme called "social interaction". (b) Data that indicated the participants" 
interpretations of the space within which their social interactions on their projects took place was the second part of the social level of analysis and is discussed in the theme "PBL classroom as safe space." Together these two parts capture how students made social sense of their projects. Lastly, to capture the change in participants' subjective meanings, the activities and experiences that changed the way participants felt about themselves is captured by the theme "impact on subjective experience of self."

\section{Individual Level Analysis}

\section{Influence of personal history.}

One of the ways that participants described their experiences was through an interpretive process based on their individual characteristics, experiences, and history. These interpretations guided their actions in their projects (Blumer, 1986; Spradley, 1979). For example, Peter, a graduate who was working full time in industry, described his PBL experience similar to working in a manufacturing environment much like where he was currently employed:

We had multiple projects where we had to come together as a group, formulate some plan to assemble a set of something ...make the parts, assemble the parts, verify that everything worked and then produce a finished project for our teacher...Very similar to what you would see in a manufacturing environment; or it's just stretched out over a longer period of time, I guess like a research and development you would think of. (Peter) 
Peter used his own technical background and work experience to interpret what needed to be done on his project (Spradley, 1979). For Gary, a graduate who worked as an electrician, the tools he had previously used in his job gave his classroom experience meaning. Moreover, the applicability of skills learned at SCC demonstrated the realworld aspect of projects in PBL (Bell, 2010):

In hands on courses for the electronics, we trouble shoot, we used oscilloscopes and things like that. Those things that I had previously touched, but now that I got to go on a classroom. I really learned it, you know. There are a lot of times we do things that we just do, because that's what we're supposed to do. But we don't have the knowledge of how they really operate and what they're doing. So now I have a lot of that inner knowledge. And it grows daily because I can put two and two together from what I've learned in the classroom. (Gary)

Gary described above the tools he used as one of the common things between his past work, his PBL class, and his current work. He also described the differences in his understanding of what the tools can do in these three contexts. Therefore, the changes in his knowledge of the tools and their uses defined his PBL experience (Blumer, 1986). Through this interpretive process, the meaning of this equipment continued to change as he worked and learned more (Blumer, 1986).

This research shows that experiences in PBL are interpreted differently by these individuals based on their own characteristics, history, and experiences. Furthermore, individuals connected their experiences in PBL classes with their work life, a connection 
made possible because of the nature of PBL. This connection makes what they learn in the PBL class relevant to their work and their career goals.

\section{Social Level Analysis}

\section{Social interaction.}

Another way that participants described their experiences in a PBL class was in terms of the social interactions they had with their project team members. Mark, a graduate, described his initial experience with PBL as socially awkward and perhaps even uncomfortable:

The first day or the second, you had to get with people and you weren't real sure how they're going to act because we have never really worked with them before. At least you might never have met them before. So, you might be catching their names, "Hey, how're you doing, man? Well, let's see what we can do with this piece of paper here, see if we can make it the tallest [he is describing the project]". I would say just because you have a project, you have a goal. You're looking for this outcome. So, you would have to figure out a way to reach that goal working with the people you're with, working with the materials provided and in the time allotted. (Mark)

A symbolic interactionist would claim that people act towards things based on the meaning that things have for them (Blumer, 1986), and that perspective can be seen in Mark's statement above. For Mark, doing a project meant having a goal that he could reach by working with others. Furthermore, he saw that working as a team carried the 
risk of being with people who might not do their part and that could have a negative impact on him as he explains below:

As long as you have some people there to work with you, then it would be fun. But then, if you have people there that don't want to do nothing, lazy, don't really care, then, you know, you just got to do a little bit more. (Mark)

He continued to explain that his experience was a positive one on his project:

It went smoothly. So, as long as everybody was interested, I could say that it just goes smoothly. Everybody was on the same page. Everybody knows their part and it all comes together real quick. (Mark)

Even though Mark did not talk about explicit rules, he said that working well together made things go smoothly. His comments implied that there were certain implicit rules, ones that likely came about as the group members interacted with one another. It was the social processes in the group that created and upheld the implicit rules (Blumer, 1986), as Mark explains below:

Let's say materials. Like this person gets this. This person gets that and this person gets that over there where we'll bring it all together and each of us put a hand in them and see what comes out. You know, kind of all of us shape it. Shape the - the color to product. (Mark) It appears that for Mark, the project and the product were shaped by the interactions of the members of the team. Through these interactions, common meanings among the team members emerged (Blumer, 1986). Therefore, to get the job done, team members did 
whatever they saw was needed to be done based on their interpretation of their interactions and the common meanings that emerged as a result of these interactions. Another benefit of teamwork was developing friendships. To Ben, a student, friendship also meant something like a support group:

You got to work together and you got to know each other a lot, which also worked out well because you make good friendships that way. Also just being in school and being able to rely on each other, knowing what each other's skills are - well you got this, and so you got this, so can you show me how to do this. (Ben)

The supporting environment that developed as a result of working in groups in PBL allowed members to rely on each other for the different skills that each had. This reliance on each other involved negotiation and contributing different skills in completing the project.

For Don, the social interaction process allowed for the team to select the best solution. Don called this a "consensus of ideas":

So, you know, in this program, they push you towards excellence. And whatever is the best solution typically we ride with, do you know what I mean? It's kind of a consensus of ideas. (Don)

According to Don, consensus allowed the team to get the project completed, but it also left room for negotiation in this constantly interpretive process. Interactions among project team members forced each member to adjust his own behavior by taking into 
account others' behaviors (Blumer, 1986). Eventually, each person adjusts what he does based on what others are doing, and in Don's project this process resulted in consensus. Consequently, even though individuals on project teams may have had different backgrounds and different meanings for things, they were able to form a new joint action plan that incorporated their past experiences and knowledge.

This study shows that social interactions in PBL allowed students to develop common meanings (Blumer, 1986). These meanings include implicit rules and behaviors within the team that are required for successful products to emerge. For instance, for Gary the importance of effective teamwork was reinforced by the success his team had on their project:

So everybody had a specific or designated part. But when all the parts had come to be laid out on a table, we were able to sit down as a group and we review each other's part, before we all put it together as one. Put out the visual and made the presentation and that project itself, the confirmation of it that the work was so nicely done, it's still showing itself. In other words, we're still getting recognition for it, it is being talked about and things like that. So it lets you know that communication or that working together was a good thing. (Gary)

Many students believed that success was a result of teamwork. This appears to be an example of the PBL experience promoting social learning as students become proficient in communication, negotiation, and collaboration (Bell, 2010; Grant, 2011; Helle, Tynjälä, \& Olkinuora, 2006). 
Participants discussed the technical and social skills that they had learned in the context of their social interactions with others and their individual characteristics and history. For instance, the social aspect of the project contributed to the information that

John learned technically. This experience was different from his previous experience that he called traditional learning:

I like project-based, that kind of learning more than traditional learning, just worksheets, and actually doing something, learning through projects with teams. I think I learned a lot more doing that way or I understand the material more when there is someone else I'm doing projects with....Share ideas, you know...It was hands-on and it made you think and then when you're finished you knew you did something because the circuit would work, you could see the results. (John) Social interactions, whether positive or negative, are an integral and primary characteristic of PBL. The kind of social interactions that are engendered in PBL color the students' positive experience of PBL.

\section{PBL classrooms as safe space.}

Students were able to take risks in their PBL classes that they may have been hesitant to take elsewhere for fear of negative consequences. As Tom explains, he overcame his fear of public speaking, something that he had much trouble with previously: 
To stand up in front of crowd of people that I don't know, that I don't associate has always been terrifying for me. And that was the first thing that made that class so special. (Tom)

For Tom, PBL meant being in a place where he could try something that he had not been successful at elsewhere. For Peter, also, the authentic learning aspect of PBL provided a place for him to practice what he needed to know for work:

I would say it's very helpful being able to apply and really getting in there doing what you would do in your job. I guess you could relate to being a rehearsal for a dance or something like that, you're trying it out before you actually do it. (Peter) PBL class was clearly a place where Peter could take risks and make mistakes without negative consequences. He goes on to explain:

It allows you to get your hands dirty, make the mistakes that you can make so that you provide an employer the best you can do. You're still going to make mistakes but you learn a lot by doing it. That's my impression, that's the way I learned the best. (Peter)

For Peter, PBL was also a place where he was able to do the learning that he needed in order to succeed at his job.

As these interviews show, students' reliance on each other's technical skills to get their project done lowered their risk of individual failure. This learning situation is different from a more traditional and competitive environment where each individual needs to perform at his best and have adequate knowledge to get a job done without 
making a mistake. Thus, one of the areas where PBL learning differed from learning on the job was that it allowed a safe place for students to take risks and learn things that they might otherwise have been reluctant to attempt.

\section{Subjective Level Analysis}

\section{Impact on subjective experience of self.}

Much like the social interactions that students have within their own project teams, presentation of projects to an audience is the social interaction that students have with people outside of their own team. This experience has changed the way students think about themselves. Presenting a completed project to a select audience is a characteristic of PBL (Grant, 2011). In making presentations, these students received praise and acknowledgement for their successful projects which made the experience a positive and memorable one for them. In their descriptions of this experience, participants spoke emotionally about their projects, showing pride and a sense of ownership. For them, it was a memorable event:

It was nerve wracking and it was exhilarating but we did it and we were told what a great job we did and that was my most memorable experience. (Tom) Another student offered the following:

Presenting that to our instructors and saying we know what we're doing you know, this is our project, we own this you know. So it was really a cool feeling. (Peter) 
Emotions affect identity (Stets \& Burke, 2000), with positive emotions being selfverifying (Stryker \& Burke, 2000). Therefore, it is likely that this experience had an impact on how the students felt about themselves in this environment (Stryker \& Burke, 2000).

For Gary this success had an impact on his attitude towards college:

That was a project in which I dedicated time to and thought to and I think it really may've been a jump start to my college because, in-depth thinking was challenging,..., so I really think that inspired me a little more to even push even harder in school. (Gary)

Gary continued to say "I found me in - within the community college. I really have found me." This success appears to have had a huge impact on his educational goals. Since Gary is an African American who had dropped out of a 4-year college some years ago, this kind of experience may have been critical for his retention in community college.

The presentation of his project to an audience was a new experience for Tom and that made his PBL project different from projects that he had done in the past. He interpreted his success in doing something that he saw as a new experience:

It was more like, I was learning how to put a project together and present it. And then I was teaching how this project is supposed to work [to his teammate]. And it was, a kind of a dual role for me, so that made it special too... I was excited about helping him understand that and also the fact that I was getting into something 
from scratch, you know, from nothing, build a project and expect it to work and then having to work out all of the problems. (Tom)

Tom, a 53-year old African American who had become unemployed prior to enrolling at SCC, felt accomplished and empowered by this experience.

One of the critical outcomes of PBL in technology education in a community college is an increase in student confidence and self-esteem. This change in the way they thought about themselves is particularly important for students from low socio-economic background and students of color who are underrepresented in STEM and least likely to finish community college:

"It's definitely a confidence builder." (Peter).

"More confident...I really actually felt more confident going into my part time job because, I was really knew what I'm doing now" (Gary).

It has boosted my confidence and self-esteem greatly... seeing at my age, I'm able to go back and get straight As, you know, which I never gave myself an opportunity to do before, it's just making me feel great, it really has. (Ben) The data above shows that this boost in their level of confidence affected how they saw themselves in their jobs and in their educational achievements.

\section{Trustworthiness}

To ensure trustworthiness in this study, the concepts of credibility, dependability, and transferability (Graneheim \& Lundman, 2004) have been used. Granheim and Lundman (2004) define credibility as a concept that deals with how well the data and 
analysis of the data address the research question. This includes the selection of participants and data gathering approach. I have explained the theoretical framework and the epistemological view adopted in this study, and discussed how and why the participants were selected. Another aspect of credibility is to see whether or not various experts would agree with the way the data has been analyzed (Graneheim \& Lundman, 2004). I have done this with three members of the faculty in the graduate school of education at my university. One of the three individuals is the primary investigator on the larger research project while the other two are not associated with the project. This approach has provided me with assurance that my data analysis can be considered credible.

Dependability is the degree to which the researcher's decisions during analysis leads to changes in the kind of data that gathered over time (Graneheim \& Lundman, 2004). In this study, all participants were asked the same questions and the data was gathered over a three-day period. Differences in the follow up questions that were used as probes by the interviewer were to elicit complete answers from the participants or clarify their answers to questions.

Lastly, transferability is the extent that the findings can be generalized (Graneheim \& Lundman, 2004). This study is intended to provide information about how some community college students' perceptions of PBL in technology education. However, the findings of this study concur with previous research on this topic that has been discussed in the literature review of this study even though this student population 
was different from the studies reviewed. Thus, the findings may provide a degree of transferability to other technology student perspectives in community colleges.

Alternative explanations for my results are quite possible. For instance, if the data sample included women, a rarity in this program, it is possible that they might have experienced a project-based learning as minorities very differently. On one hand, the PBL approach, which appears to work successfully with men of different races, ages, and backgrounds, might be used to increase the number of women in this program. On the other hand, PBL requires intense social interactions inside the classroom which might be influenced by the socio-cultural norms regarding gender outside of the classroom. These norms could influence women's experiences in different ways. Thus, although this study reflects positive aspects of PBL for this student population, studies that describe women's experiences in this context might provide a different perspective on the topic.

\section{Conclusion and Implications}

The eight participants in this study came from low socioeconomic backgrounds and four were students of color. Sixty percent or more of students from such backgrounds who attend community college are likely to drop out (Bailey \& Morest, 2006; Hoachlander et al., 2003). Thus, the positive findings of this study have a number of consequences for technology programs in community colleges:

1. The PBL approach may be well suited for classrooms in which students come from backgrounds that reflect the diversity of community college population; that is, diversity in socioeconomic, race/ethnicity, work and life experience, and age. 
The findings indicate that regardless of their backgrounds, students are able to connect their individual histories and experiences to the PBL activities they encounter in the classroom. They are thus able to make sense of what they do and become engaged. The result is that they may emerge more confident and with a positive view of their abilities, as did some participants in this study.

2. Many technology education programs generally focus on teaching technical content but do not teach the social skills component needed to help students learn the kind of teamwork they will probably encounter in a job or career setting. This study has shown that PBL pedagogy can successfully fill this gap.

3. PBL appears to provide students the space and the kind of experience that helps them in the successful completion of an associate's degree in a high-paying STEM field (Terrell, 2007). Armed with an associate's degree, the current students and the four of the graduates have the kind of skills and access to opportunities that their parents did not have. Furthermore, students who were over the age of 40 and unemployed had either obtained employment after completion of their associate's degree or were sure to do so once they completed it.

4. Some of the participants indicated that their experience at SCC had made them interested in continuing their education and receiving a bachelor's degree in a 4year college. This finding may indicate that the PBL experience has left students with a positive feeling about technical education. Thus, PBL appears to be a pedagogical approach that allows community college students an equitable means 
of achieving community college success in technical education and the confidence to think of pursuing a bachelor's degree.

In sum, these findings have clear implications for expanding access and success in technician and engineering education for students at the community college.

\section{Acknowledgement}

This material is based upon work supported by the National Science Foundation under Grant No. DUE 1003589. Any opinions, findings, and conclusions or recommendations expressed in this material are those of the authors and do not necessarily reflect the views of the National Science Foundation.

\section{References}

Aksan, N., Kisac, B., \& Demirbuken, S. (2009). Symbolic interaction theory. Procedia Social and Behavioral Sciences, 1(1), 902-904.

Bailey, T., \& Morest, V. S. (2006). Defending the community college equity agenda (1st ed.). The Johns Hopkins University Press.

Baillie, C., Pawley, A. L., \& Riley, D. (Eds.). (2011). Engineering and Social Justice: In the University and Beyond. Purdue University Press.

Bell, S. (2010). Project-based learning for the 21st century: Skills for the future. The Clearing House: A Journal of Educational Strategies, Issues and Ideas, 83, 3943. doi:10.1080/00098650903505415

Blumer, H. (1986). Symbolic interactionism: Perspective and method. University of California Press. 
Bogdan, R., \& Biklen, S. K. (2006). Qualitative research for education: An introduction to theories and methods (5th ed.). Boston: Allyn \& Bacon.

Charmaz, K. (2011). Constructing grounded theory - A practical guide through qualitative analysis. Los Angeles, London, New Delhi, Singapore, Washington DC: Sage Publications.

Coyne, I. T. (1997). Sampling in qualitative research. Purposeful and theoretical sampling; merging or clear boundaries? Journal of Advanced Nursing, 26(3), 623-630. doi:10.1046/j.1365-2648.1997.t01-25-00999.x

Creswell, J. W. (2009). Research design: qualitative, quantitative, and mixed method approaches. Thousand Oaks, Calif.: Sage Publications.

Frank, M., Lavy, I., \& Elata, D. (2003). Implementing the project-based learning approach in an academic engineering course. International Journal of Technology and Design Education, 13, 273-288.

Graneheim, U. H., \& Lundman, B. (2004). Qualitative content analysis in nursing research: Concepts, procedures and measures to achieve trustworthiness. Nurse Education Today, 24, 105-112.

Grant, M. (2011). Learning, beliefs, and products: Students' perspectives with projectbased learning. The Interdisciplinary Journal of Problem-Based Learning, 5(2), $37-69$. 
Hakimzadeh, H., Adaikkalavan, R., \& Wolfer, J. (2011). CS0: A project based, active learning course. International Transaction Journal of Engineering, Management, \& Applied Sciences \& Technologies, 2(5), 493-506.

Helle, L., Tynjälä, P., \& Olkinuora, E. (2006). Project-Based Learning in Post-Secondary Education - Theory, Practice and Rubber Sling Shots. Higher Education, 51(2), 287-314. doi:10.1007/s10734-004-6386-5

Hoachlander, G., Sikora, A. C., \& Horn, L. (2003). Community College: Goals, academic preparation, and outcomes. Education Statistics Quarterly, 5(2), 121-128.

Jonassen, D. H. (2000). Toward a design theory of problem solving. Educational Technology Research and Development, 48(4), 63-85.

Jonassen, D. H. (2012). Designing for decision making. Educational Technology Research Development, 60(2), 341-359.

King, C. J. (2012). Restructuring engineering education: Why, how and when? Journal of Engineering Education, 101(1), 1-5.

Lehmann, M., Christensen, P., Du, X., \& Thrane, M. (2008). Problem-oriented and project-based learning (POPBL) as an innovative learning strategy for sustainable development in engineering education. European Journal of Engineering Education, 33(3), 283-295. doi:10.1080/03043790802088566

Malcom, L. E. (2013). Student diversity in community colleges - Examining trends and understanding the challenges. In J. S. Levin \& S. T. Kater (Eds.), Understanding community colleges (pp. 19-35). New York and London: Routledge. 
McDavid, J. C., \& Hawthorn, L. R. L. (2006). Program evaluation \& performance measurement: An introduction to practice. Sage Publications, Inc.

McLoughlin, L. A. (2012). Community colleges, engineering, and social justice. In C. Baillie, A. L. Pawley, \& D. Riley (Eds.), Engineering and social justice - In the university and beyond (pp. 123-142). West Lafayette, Indiana: Purdue University Press.

Meacham, J. A., \& Emont, N. C. (1989). The interpersonal basis of everyday problem solving. In J. D. Sinnott (Ed.), Everyday problem solving: Theory and applications. New York: Praeger.

National Center for Education Statistics. (2011). Table 205. Total fall enrollment in degree-granting institutions, by level and control of institution, attendance status, and sex of student: Selected years, 1970 through 2010. Digest of Education Statistics. Retrieved December 21, 2012, from http://nces.ed.gov/programs/digest/d1 1/tables/dt11_205.asp

Prawat, R. S. (1996). Constructivisms, modern and postmodern. Educational Psychologist, 31(3/4), 215.

Silverman, D. (2011). Doing qualitative research: a practical handbook. Los Angeles: SAGE.

Spradley, J. P. (1979). The ethnographic interview. New York: Holt, Rinehart and Winston. 
Stets, J. E., \& Burke, P. J. (2000). Identity theory and social identity theory. Social Psychology Quarterly, 63(3), 224-237.

Strutz, M. L., Orr, M. K., \& Ohland, M. W. (2012). Low socioeconomic status individuals: An invisible minority in engineering. In C. Baillie, A. L. Pawley, \& D. Riley (Eds.), Engineering and social justice - In the university and beyond (pp. 143-156). West Lafayette, Indiana: Purdue University Press.

Stryker, S., \& Burke, P. J. (2000). The past, present, and future of an identity theory. Social Psychology Quarterly, 63, 284. doi:10.2307/2695840

Terrell, N. (2007). STEM occupations: High-tech jobs for a high-tech economy (pp. 2633). U.S. Bureau of Labor Statistics. Retrieved from http://www.bls.gov/opub/ooq/2007/spring/art04.pdf 


\title{
Paper 2
}

\section{Acquiring Professional Identities in Project-Based Learning in a Community College}

\begin{abstract}
This qualitative methods study examines how technology students' experiences in project-based learning (PBL) in a Southeastern Community College (SCC) may have affected their professional identities. Of the eight participants, four were African American males and four White males from low socioeconomic backgrounds, both populations underrepresented in science, technology, engineering, and mathematics (STEM) fields. The findings indicate that the students' experiences in PBL increased their self-esteem, allowed them to develop a technician identity, helped them persevere in community college, and gave them the confidence to plan for a brighter future. Keywords: technician identity, PBL, STEM, identity, community college, professional identities, technician education
\end{abstract}




\section{Introduction}

Analyzing of the perspectives of students who experienced project-based learning $(\mathrm{PBL})$ in a technician education program in a Southeast community college (SCC) revealed that students experienced a change in their sense of who they were and what they could accomplish academically and professionally in a PBL environment (Noravian, 2013). This paper builds on the earlier study by investigating if specific PBL processes can be connected with changes in students' professional identities. This study is significant because understanding how students interpret their experiences in PBL could help community college technology instructors determine the feasibility of implementing or integrating any part(s) of the PBL process into other technology programs to increase students' interest in pursuing science, technology, engineering, and mathematics (STEM) education.

\section{Identity Theory}

Identity is an important analytic tool for understanding schools and society (Gee, 2000). In contrast to focusing on the "sometimes overly general and static trio of race, class, and gender" (Gee, 2000, p. 99), people's identities allow educators to examine their behaviors within the context of educational practices and educational institutions (Gee, 2000). Thus, examining identities allows us to study how individuals make sense of their experiences in an educational institution, rather than interpreting their experiences based only on their race, gender, or class. 
Identities are meanings that individuals attribute to themselves and that others attribute to them defining what it means to be who one is in a role or situation (Blumer, 1986; Burke \& Tully, 1977; Goffman, 1959). Individuals have different identities that are derived from interactions with others in different situations (Blumer, 1986; Burke, 1991). Thus, a student's identity is situationally and socially constructed.

Moreover, in each situation, individuals organize their identities into a hierarchy that is meaningful in the situation (Burke \& Reitzes, 1981). As a person has a variety of identities, the activation of a particular identity in a given situation allows an individual to accomplish her social and/or personal goals (Stets \& Burke, 2000). Thus, an individual may activate his/her identity as a student in the classroom or as a parent in the home.

Identity theory guides this research in understanding the commitment of students to an identity, the salience of a particular identity, a student's motivation to take certain action, and the self-esteem and educational commitment that may result. For example, if a student considers part of his identity to be a successful student in a project-based classroom, he will make sure that his project succeeds by meeting deadlines, performing well, and fulfilling other criteria because of his commitment to this identity (Stets \& Burke, 2000). He might accomplish this by such behaviors as contributing technical solutions to the project in the best way he can because this is the meaning that he will associate with this identity (Burke \& Reitzes, 1981). He might also teach others in the project skills that he may have, learning from others what he doesn't know, always attending class and keeping up with the work, resolving conflict in ways that will not lead 
to the failure of the project, working well with others by cooperating and making compromises, working outside of the classroom time if need be to complete the tasks, and so on. These actions will result in the social confirmation of his identity as a successful PBL student (Burke \& Reitzes, 1991). When these behaviors allow him to complete projects successfully, he is likely to feel that he is able to control the situation around him to succeed in his project. This process of self-verification (Stets \& Burke, 2000) will lead to efficacy-based self-esteem (Cast \& Burke, 2002) . Furthermore, if a student receives positive feedback by fellow students and instructors, he is likely to feel that his behavior is valued, leading to an increase in worth-based self-esteem (Cast \& Burke, 2002; Gecas, 1982).

\section{Project-Based Learning}

Project-based learning is a learner-centered pedagogical strategy in which student activities are focused on producing end products that address specified ill-structured problems (Savery, 2006). According to Jonassen (2000), a problem is an unknown in any situation. Problems differ in how well they are defined or structured and how routine they are (Mayer \& Wittrock, 1996). Well-structured problems are solved through applying concepts or principles being studied to a routine or constrained problem situation (Jonassen, 2012). Ill-structured problems, on the other hand, are found in everyday life, have aspects that are not well specified, have a variety of solutions or no solution, and often require an interdisciplinary approach to solve (Jonassen, 2012). As Savery states, "Problems in the real world are ill-structured" (Savery, 2006, p. 13). 
Project-based learning with ill-structured problems require that students make decisions based on their contextual interpretation of the problem, which creates space for social interactions (Meacham \& Emont, 1989). Students actively participate in defining and finding solutions to a problem that often results in a product while the teacher acts as a guide or facilitator (Bell, 2010). This practice promotes social learning so that students become proficient in communication, negotiation, and collaboration (Bell, 2010; Helle, Tynjälä, \& Olkinuora, 2006). Learning takes place through the process of developing a solution, so the end product is important to the learning goals (Grant, 2011; Helle et al., 2006). Furthermore, learning is self-directed and self-regulated (Worthy, 2000). In other words, the learner controls the process of learning (Helle et al., 2006).

Research that examines PBL-based STEM programs in post-secondary education illustrates various ways that PBL is used and the consequences of this approach on student learning. Some examples include providing students a more feasible approach to addressing complex real-life problems (Lehmann, Christensen, Du, \& Thrane, 2008), testing non-traditional delivery of curriculum (Frank, Lavy, \& Elata, 2003), and developing skills in at-risk students in order to improve retention in the more traditional classes (Hakimzadeh, Adaikkalavan, \& Wolfer, 2011). These studies examine PBL-based STEM programs at four-year institutions. Furthermore, the studies do not examine student professional identities. In contrast, this study focuses on students in community colleges who are involved in technical programs and examines how the PBL process that students describe may have affected their professional identities. 


\section{Characteristics of Community College Students}

A community college is the first step in post-secondary education for many students in the United States. Of the 7.5 million students enrolled in two-year colleges in 2010, 56\% were part-time (National Center for Education Statistics, 2011), 57\% were independent students who came from families with a yearly income less than $\$ 36,000$, $40 \%$ were racial/ethnic minorities, and nearly $38 \%$ were first-generation college students (Malcom, 2013). Moreover, community college students are likely to be academically underprepared, have dependents, and be older than 24 (Bailey \& Morest, 2006). Thus, nationally students of color and low income students are more likely to attend community college than a four-year college.

Students of color and low income students are most likely to drop out without completing their programs in community college. Sixty percent or more of the students who drop out are African American, Hispanic, or low income (Bailey \& Morest, 2006; Hoachlander, Sikora, \& Horn, 2003). Thus, even though these students are provided access to community college, their low level of completion indicates an inequitable educational experience in the community college. Keeping students of color and low income students in STEM courses is the motivation for this study.

\section{Method}

This study investigates if specific processes in ill-structured PBL classrooms can be connected with changes in students' professional identities in a community college technology program. A qualitative research approach (Blumer, 1986; Bogdan \& Biklen, 
2006; Spradley, 1979) was used to collect and analyze data for this study. I conducted eight face-to-face interviews with technology students who were or had been engaged in PBL at SCC. The interview protocol included open-ended questions specifically focused on the students' experiences in their PBL classrooms. For instance, students were asked to discuss their PBL class and what they did, their experiences, feelings, and challenges. The interviews were developed to elicit student experiences and their interpretations of their experiences in PBL classrooms, and to analyze their interpretations to give meaning to and influence their interactions with others. The length of each interview was approximately one hour and was conducted either at SCC or a local coffee shop.

The participants were selected by selective and purposeful sampling (Coyne, 1997). Students had been pre-selected for the interview by a faculty member at SCC, based on information provided by the primary investigator on the larger study, to reflect diversity in age, race, background, sex, and program of study. The purpose behind this sampling technique was to identify and interview individuals who would be able to provide "information-rich" data (Coyne, 1997, p. 624) about their PBL classroom.

All interviewees were male and lived nearby the community college. They were diverse in terms of age, race, part-time/full-time status, marriage status, employment status, experience, and time spent in the program. The participants represented the typical community college student populations in that they came from working-class families and were the first in the family to attend college. Four of the eight participants were African American, while the other four were White. Appendix 1 lists the 
participants and their backgrounds. The participants had not experienced PBL classes together. When asked to describe a project in their PBL class, each participant described a different project in which the participants worked with team members to produce a product, with the instructor acting only as a guide. Each project was one semester long. A collective case study method, also known as multiple-case studies (Baxter \& Jack, 2008; Silverman, 2011), where each one of the eight individual was treated as a case, was used to investigate the research question. This approach uses the constructivist paradigm (Creswell, 2009) which assumes that there are plurality of views and reality is socially constructed (McDavid \& Hawthorn, 2006). The coding was done to extract the various processes of PBL described in each case. Then common elements between cases were selected as the common processes that students experienced in their PBL classrooms (Baxter \& Jack, 2008). Then using identity theory, I examined whether students had experienced identity changes within these processes.

The data analysis was reviewed by three members of the faculty in the graduate school of education at my university. One of the three individuals is the primary investigator on the larger research project, while the other two are not associated with the project. This approach has provided me with assurance that my data analysis can be considered credible (Graneheim \& Lundman, 2004).

To ensure dependability (Graneheim \& Lundman, 2004), all participants were asked the same questions and the data was gathered over three consecutive days. 
However, different follow up questions were asked to elicit complete answers from participants or to clarify their answers to questions.

\section{Results}

\section{Context}

Southeastern Community College (SCC) is located in a low-income area with little formal education. SCC is located in rural county where the per capita income in the county is low, only $\$ 20,036$. Of the county's adult population, $8 \%$ have only a kindergarten to $8^{\text {th }}$ grade education while $15 \%$ have a $9^{\text {th }}-12^{\text {th }}$ grade education. Thirtythree percent of the county's population has only a high school diploma, with $22 \%$ who have some college education, but no degree; $8 \%$ have an Associate of Arts degree, $10 \%$ hold a Bachelor's degree, and 5\% have earned a graduate degree ${ }^{1}$.

\section{Processes and Elements Described by Students}

In this study, I focus on identifying the processes experienced by participants and the self-perceived identities (Kaufman \& Feldman, 2004) formed by students and graduates who have experienced PBL. The various process that most participants described as having experienced has a number of distinct elements. Since not all the students enter the PBL class from the same place in their program, for the purpose of this study, the processes that are considered are entry into SCC and the project-based learning class. The reason for this choice is to show the identities of the students when they entered SCC and when they leave their PBL class.

\footnotetext{
${ }^{1}$ This information is acquired from public data available on the county.
} 


\section{Student educational goals upon entering.}

The educational goal that students discussed before entering SCC appeared to be a key driver in their choice of technology program (electronics, sustainability, or mechanical). Moreover, for some students, attaining their educational goal may have seemed out of reach previously. When they were given an opportunity to study towards achieving their goal, they took it. For instance, Ben, who had become unemployed, was enrolled in the electronics technology program at SCC:

I've always wanted to do electronics. And so when I lost my job I decided I had to think, from the employment Security Commission, said I can get a Pell grant to go back to school. (Ben)

For other participants, pursuing their educational goal was a choice. Don, a contract writer and a veteran, was enrolled in the sustainability program at SCC. He worked as a contract writer while he attended SCC:

I had kind of given up and it was more of like, ..., you know go back to the workforce and put on the ties, you know, go back to the work. But as I got deeper into writing, I realized that instead of looking at the current situation and working from home ..., I'd looked at it more of as, okay, I'm going to own this, this is my business, I'm going forge forward and add to it, instead of taking away.. and that, that really empowered me, I guess you could say at the time, to kind of take fate in my own hands and say, "Okay, where do I want to go from here, what do I want to build on here, what do I want to accomplish?" [Looking 
at] the SCC brochure and the classes that they had and I saw that they had sustainability technologies. And I was just smiling all the way through. I get this warm and fuzzy feeling, I guess that some people say that they get, you know - I was just like, wow. (Don)

Yet for others, their educational goal upon entering SCC was a means to moving up the ladder in their place of employment. Mark had just completed his industrial systems technology associate's degree:

I've been working where I'm working at for about three years. And I was talking to them about, you know, moving up the ladder. And they said, "Well, the first thing you got to do is graduate college... And talk to us when you get through" So, this community college being local, I decided to come here. (Mark)

There were also students whose educational goals were perceived to be a ticket to a better life. An example of this was Peter, a graduate from SCC, who wanted something different for his family than the one he grew up in:

My parents both are not college educated. And I saw that they were sort of stuck. And I didn't want to be in that position that was financially, jobs and you know, sort of tough seeing them stuck in that position. And I know I didn't want to be there and put my family in that same situation later on in life... I was seeing a lot of the kids I went to school with. They didn't get their education. The people you thought were to succeed in life and it didn't happen it's sort of, you know, makes you think you really need an education. (Peter) 
In these student statements, they all express a desire to change their life and job circumstances. I interpret educational goals as identity goals of students upon entry; these are preferred identities that participants assume, desire and plan for (Charmaz, 2011). Although the various identity goals and the motivations behind these goals differed, what was similar was that participants realized that a certain level of education was needed for them to achieve these goals. Thus, achieving their identity goals meant obtaining further education.

\section{Project-based learning experiences.}

Students develop various identities based on their experiences in the PBL classroom. These included team and role identities with the team, technician identities, and new identity goals (Charmaz, 2011). As the data analysis shows, they were also able to exercise individual multiple identities in the context of the PBL classroom.

\section{Gaining team member identity and role identity in the process of team}

\section{formation.}

In the process of team formation, students acquire a new identity: team member and a role identity within the team. These identities have consequences in the way students behaved and ultimately affected the completion of their projects. When students first became part of a team, they did not know the other team members. Getting to know the others involved a number of different steps, some of which were perhaps undertaken at different stages of the project. For instance, one of the first steps after students were put in teams was collecting information about other participants, such as names, phone 
numbers, and emails. This process required bypassing the formalities of normal social interactions, in which people collect contact information selectively and only from people they have gotten to know and like. Team members also had to establish a communication protocol about how they would communicate their project status with each other.

Within the team individuals also developed role identities. Another step in team formation involved students finding out each team member's specific technical expertise and how each member could contribute to the project. Thus, each team member acquired a unique role identity within the team that was based on the specific project (Blumer, 1986; Burke \& Tully, 1977; Goffman, 1959). During the project implementation, the identification of the role of each participant allowed the students to rely on each other's vexpertise to achieve their project goals.

A further step involved negotiation about the choice of their project, mode of interaction, behavioral norms of the team, and the salient identities that they brought into the team. Negotiations made things more complicated, as this student noted:

We decided on the project but it took us two week to determine which project we wanted to work over because we all had so many great ideas about all of the projects that were available for us to do. And it took a while to finally decide on a particular project. In that particular class, there were three of us in my group, and each one of us had been out in the workforce for many years. We all have a lot of different ideas about how we should do, every aspect of the project that we had to design. Well, there are some complications. But it made a whole lot of things a lot 
easier because, you know, I didn't understand pulleys. And there's another guy that's what he had been doing and it made that part of the task very simple. He explained to me why we want to use a six-inch pulley as oppose to a four-inch pulley or something like that. And the group that I was in was pretty good. We had a variety of different backgrounds and experiences and our project went together fine. No problem. (Tom)

This response shows that although initially Tom's team had difficulty in forming, they succeeded because they were able to define specific role identities based on individual technical skills that were related to their project, not just the number of years they had spent in the workforce. Thus, in the process of team formation, each person developed a team identity in relation to other members and a role identity based on their technical expertise within the team.

All participants said that their teams successfully completed their projects. When students succeeded in their projects, each team member's contribution were made visible and were acknowledged by the others in the team:

I didn't understand pulleys. And there was another guy who had worked at some company and that's what he had been doing and it made that part of the task very simple. (Tom)

Thus, the team member who knew about pulleys was considered a valuable member of the team, an identity attributed to him by others in the team (Blumer, 1986; Goffman, 1959). Cast and Burke (2002) tell us that this kind of attribution increases an 
individual's worth-based self-esteem, which refers to the degree to which individuals feel they are persons of value. Each team member reflected upon his own contributions to meeting the team goals:

We were putting together an automated systems. I have never designed a system. But I knew how all of the pieces that were needed worked. And the guys that I was working with, my partner, he had never worked with automation in any automated equipment. And so, it was me helping him to understand how each piece works in an automated system ... It was more like - I was learning how to put a project together and present it. And then I was teaching how this project is supposed to work. And it was - a kind of a dual role for me so that make it special...And so, I was excited helping him understanding that and also the fact that I was getting in to do something from scratch, you know, from nothing, build a project and expect it to work and then having to work out all of the problems ...And that I enjoyed it. (Tom)

Tom sees his technical skills as contributing towards the success of the project. He sees himself as having accomplished something that he had not done before. He is likely to attribute the success of the project partially to his performance on the project (Blumer, 1986; Goffman, 1959). This reflection upon his own contributions provides efficacy-based self-esteem (Cast \& Burke, 2002).

It appears that working in teams that succeeded in the PBL classroom affected students' identities and increased their self-esteem. This increase in self-esteem helps 
build the buffer students may need in the event they are in a class or a situation in college that is not self-verifying (Cast \& Burke, 2002). An increase in this buffer is likely to have consequences on students' perseverance at the community college.

\section{Activating multiple individual identities in the process of dealing with conflict}

\section{and frustration.}

Success on a project is the consequence of the behavior of team members within a team. Dealing with conflict, or situations that could lead to conflict or frustrations, was an aspect of teamwork that students discussed in the interviews. In one project, Ben took matters in his own hands in order to fix a problem with an uncooperative team member:

There was one class during the summer, it was completely online and it was an English class. We got grouped together and we got put into groups with people that you've never seen because it's a completely online classes and we had to go through and do projects and other things like that. Also we got graded as a project and it was kind of crazy. The person that was in charge of the group, she had - I mean this is - she had atrocious - I mean atrocious grammar. And she would send stuff in. She wouldn't get it but the rest of us would get it. I mean even if you put on Spell Check - in fact she didn't put on Spell Check on her Word when she did it. I sent it back to her [with corrections] but then she submitted the original that she did. I don't know. I don't know if she lost it or didn't know how to download files or whatever. So that got frustrating especially when I was getting 70's and stuff and I go "no this doesn't work". But then at the end of it our instructor 
allowed us to make corrections so I told her send me everything. And so she sent me everything and I fixed the thing and ended up getting A out of the class because you know I aced everything but that was kind of - I sweated a lot on those classes in the summer, this past summer. (Ben)

Ben's commitment to his identity as an "A" student lead him to do whatever he could to correct the problem and not jeopardize this good-student identity (Burke \& Reitzes, 1991). His choice of behavior was a result of his previous successes and was important for the success of the project.

Another participant, Mark, who identified himself as a leader, felt that discussion of different ideas in a team would lead to eliminating poor ideas and lead to the success of the project and everyone's success:

Any idea is not a bad idea. As long as you throw it out there and see what everybody thinks of it, you know, because other people are going to think about the things different ways. And then, they can see some things that you don't really see or, you know, so they either agree or disagree with you...So, you can't just go with one idea really... I'm the kind of person that if I don't think it's right or it's the best way to do it, I'm going to say, "Hey, why don't we try this? What do you think about this idea here?" If I think there's a little bit better way to do it, I'm going to speak up. (Mark)

Speaking up and disagreeing about ideas for projects or ways of proceeding can cause conflict. Mark saw this process to be not only a good way to solicit the best ideas 
and select the best solutions, but also as a means of displaying his identity as a leader. Salient identities are more likely to be invoked (Stets \& Burke, 2000; Stryker, 2002) along with the behavioral choices that the individual associates with that identity (Stryker, 2002). Thus, it appears that Mark was trying to activate his identity as by speaking up and negotiating with his team members.

Therefore, the process by which participants handle conflicts and frustrations within a project team involves not only behaving in ways that will lead to the successful completion of the project goals, but it also means that individuals might find the project as a means of behaving in ways that will exercise their salient identities. Thus, team members do not lose their individuality but learn to be team players and work with others towards a common goal while also activating their other salient identities.

\section{Acquiring technician identities through applying knowledge and manipulating}

\section{objects.}

One of the aspects of PBL is that students often actively participate in the production of a product that solves a problem. It is, therefore, not surprising that the most common word used by students was "hands-on," which meant that they were manipulating objects instead of just learning in the more traditional manner. This handson aspect has significant implications on student identities as it allows participants to rehearse their goals identity (Charmaz, 2011). 
Students describe the process of solving problems and their experiences in different ways. A participant in search of a different way of "doing things" expressed this feeling in the introductory semester PBL class:

I'm really realizing like, "Wow, you don't always have to do things the same way to get the same result." ... I think it intellectually, it really stimulated my senses, pushing me on in the program. (Don)

Don's experience is likely to increase his commitment to complete the program (Cast \& Burke, 2002). Another participant who had experienced the first semester PBL class said, "That's the one that put the challenge to my mind, that opened up my mind for thinking" (Gary). Gary had attended engineering school in 1983 but had dropped out after one year. In 2007, upon becoming unemployed, he returned to SCC to get his associate's degree in electronics technology. On entering the program, he was "scared" and uncertain as to whether he could deal with the academic challenge. In the introductory PBL class, his group successfully completed their project and this experience changed the way he thought about himself: "It let me learn how [to do] in depth thinking, I can do it and what I was capable of doing" (Gary). He found that this experience motivated and made him, in his words, "push even harder in school." Gary spoke about many other hands-on experiences, in which they applied what they learned in the classroom and in his job. It was this ability to apply what he learned that allowed Gary to transition from a person with a negative educational experience in the past, to one who could achieve his identity goal. This realization increased his self-esteem (Cast \& Burke, 2002) and his 
commitment to successfully complete his educational goal, which was an associate's degree (Cast \& Burke, 2002).

For a high school participant whose goal was to become an electrical engineer, the hands-on aspect of PBL was a highly validating experience:

Maybe the first week or two - probably the first two or three weeks maybe it was just sitting and we were learning safety and then after that we never sat anymore. As soon as you came in we got right to the wiring and [when] we finished we could leave...We did everything, like we didn't sit and just write and take notes... we got up and we actually wired the box by ourselves. Well the first week we had teams but after that we wired them by our self. We had our own box to wire - it was a, you did everything yourself. It was you, you relied on your hands, your own knowledge...It was hands-on and it made you think and then when you're finished you knew you did something because the circuit would work, you could see the results. (John)

Applying his knowledge to creating may have helped John experience what he perceived to be his goal identity (Charmaz, 2011). His reflection on his experience of success likely increased his efficacy-based self-esteem (Burke \& Stets, 1999).

For Peter, who worked on an independent project with one other student, the experience of applying what they had learned to creating a product was a "rehearsal" for a change in his identity: 
I would say it's very helpful being able to apply and really getting in there doing what you would do in your job. It's pretty much I guess you could relate to being a rehearsal for a dance or something like that, you're - you're trying it out before you actually do it... It allows you to get your hands dirty, make the mistakes that you can make so that you provide an employer the best you can do. You still going to make mistakes but you learn a lot by doing it. It allows you to walk into the work place and know that you at least have some idea about what you getting yourself into. You're not walking into a room full of stuffs that you have no idea about, you're educated and you know you're educated, so it's definitely a confidence builder. (Peter)

This experience in this PBL classroom provided Peter the ability to transition between his student identity and his current work identity.

This process of applying knowledge and using their hands to make a product was a broadening experience that allowed participants to not just experience their own identity goals but to discover their own capabilities. One participant described his experience working on his project as that of a teacher and as a project lead, identities that he had not had before; he also designed a system, also new for him:

We were putting together an automated system. I have never designed a system. But I knew how all of the pieces that were needed worked. And the guy that I was working with, my partner, he had never worked with automation in any automated equipment. And so, it was me helping him to understand how each piece works in 
an automated system and then he and I deciding, well we're going to use this, we're not going to use that or how fast we wanted to go, how slow we needed to go, how many different stations we got to have and why. It was more like, I was learning how to put a project together and present it. And then I was teaching how this project is supposed to work. And it was, a kind of a dual role for me so that make it special ...And so, I was excited about helping him understanding that and also the fact that I was getting in to do something from scratch, you know, from nothing, build a project and expect it to work and then having to work out all of the problems...And that I enjoyed it. (Tom)

The process of making the kinds of decisions that required the application of knowledge to solving a problem or creating a product allowed some participants to see the alignment of the program with their identity goals. It allowed others to experience their desired identity, rehearse a new work identity, or explore new identities.

This process appears to be self-validating and contributes significantly to the students' self-esteem. A PBL experience may be the part of the process which has the most significant impact on the identity commitment of the students (Cast \& Burke, 2002). This process essentially allows students to practice their identity goals and it produces the experience of participation in a social environment, much like a community of practice (Wenger, 2008). 
Presenting the PBL project.

Another positive aspect of PBL is presenting the completed projects to an audience. This process allowed students to receive feedback from others and to feel a sense of accomplishment, clearly impacting students' feelings of worth-based and efficacy-based self-esteem (Cast \& Burke, 2002; Gecas, 1982) and their new professional identities as technicians:

We have to give a stand up in front of the class and give a total explanation about project that we designed from nothing to completion. And the president of [SCC] was there [as were many other high level representatives from education and industry]. And I was totally nervous. We had to explain [our project] and answer all kinds of question about it. It was nerve wracking and it was exhilarating but we did it and we were told what a great job we did and that was my most memorable experience from $[\mathrm{SCC}]$ this time around. I enjoyed it...But standing up in front of crowd of people that I don't know, that I don't associate with, has always been terrifying for me. And that was the first thing that made that class so special. (Tom)

Another student described his experience in a different presentation:

And then the satisfaction of presenting that to our instructors and saying we know what we're doing you know, this is our project, we own this you know. So it was really a cool feeling. Not having had like a boss behind you saying this is what you need to do or your coworker saying this is what you need to do. This was us 
you know, we did this, we designed it, we built it, we put it together...here you go, use it and it actually works. (Peter)

The outcome of this process was not just an increase in self-esteem (Cast \& Burke, 2002), but also the ownership of their new identities (Wenger, 2008) as technicians who were able to demonstrate their competence. They are not just knowledgeable, but also capable of bringing their knowledge to fruition and doing what would be expected of them, on their own, as technicians in a job.

\section{Identifying new identity goals upon completion of PBL classroom.}

One of the outcomes of experiencing the PBL process was the development of a new identity goal. Participants thought about what they wanted to do in the future. Regardless of whether they had completed their associate's degree or whether they were in the process of doing so, they had new identity goals which were built on their successes that they had experienced at SCC, particularly in their PBL classroom. Their experience had changed their way of thinking about their future educational goals. For instance, a participant in his forties felt that he had options of either working or continuing on to a four-year degree:

Possibly going in and getting a four-year degree. And I want to test the waters after I finish my two-year course. People who graduate with a two-year degree [say] the money is not bad. (Ben)

Participants had different goals. For example, some wanted a job instead of more education: 
I'd just be glad if I can get a job getting out that will allow me to support my family, you know. And the first opportunity that, you know, I have to really change things and to use my skill set and, you know, put this into a use, I will. (Don)

A participant who had been unsure of his academic abilities when he entered SCC now expressed an interest in pursuing further education in a four-year college:

I continue to learn, I want to continue to learn, actually I would love to consider more school time...There's always more to know, when I thought before there was a limit. I mean one that's all you need to know. But there's always more in deep thinking...in a way I think often about electronic engineering. My original goal was to do electronic engineering back when I graduated high school. (Gary) Other participants saw pursuing a four-year degree would allow them to get ahead in their jobs.

Because [his boss] is going to be retiring in three years and I'm hoping maybe that would be enough time where I can at least be halfway done on my bachelor's. (Harry)

Another participant was interested in moving up to a management position with his current employer:

I'm hoping to have my bachelor's in five years. So, that'll only open more doors as time goes by. Just have to see what comes available. (Mark) 
These future goals are new identity goals, based on their current successes, for students and working graduates. All students appeared to have experienced an increase in self-esteem and felt that they were capable of learning academically. Some had ambitious goals that included reaching the top position in their companies:

I'm in a mechanical design position at the company I work for...but, at one day I would like to be at that head position in that company. Not because I want to push anybody out, but I know I'm the youngest one in the group and I hope to be in that same position my bosses are one day. (Peter)

These goals are likely to drive students' future behavior in terms of obtaining further education and advancement in their jobs.

\section{PBL and perseverance.}

The process of self-reflection in the interviews about PBL allowed participants to observe changes in themselves by comparing and contrasting the past and present and thinking about their futures. It also allowed them to acknowledge their achievements. For instance, by comparing where he was before he started college to being at college, one of the participants described it as a life-changing experience:

Before I started school I was just kind of floating around and [was] at the end of my rope and there was no jobs, not anything. And I think the last job I had I was washing dishes in a pizza place, that was the only thing I could find at that time and that the economy is terrible I mean here... And now I've been at school back 
and getting everything started and everything, my attitude has completely turned around and now I see the light at the end of the tunnel, I really do (Ben). Another participant compared his early college feelings of uncertainty about his abilities to his feelings about himself now that he had graduated:

And I did my two years there which was very enjoyable, being at my age, to be honest with you, at school I thought it would be quite a challenge at first. But I am so glad and I am so thankful that I did. It has helped me right now to feel better about myself actually. (Gary)

Gary has experienced a change in his self-esteem. He persevered through the program and feels differently about himself and his abilities.

These examples of perseverance allow participants to articulate where they are in the process of their goals and plans for their futures. Moreover, they perceive that they have succeeded when they reflect on their perseverance.

\section{Linking It All Together}

The students experiences in PBL increased their self-esteem, allowed them to develop a technician identity, helped them persevere, and gave them the confidence to plan for a brighter future. Their future plans were built with a sense of self-esteem that they state they did not have when they entered SCC, as interview excerpts show. Many participants noted in the context of being interviewed about their PBL experience that they were interested in pursuing further education, either at a four-year university or returning to SCC for retraining in specific courses. 
The two parts of the process that appeared to have contributed most significantly to a change in the students' sense of who they are and what they are capable of doing were (1) working within their teams and (2) the problem solving aspect of PBL, which required application of knowledge, manipulation of objects, and presentation of completed project to others. Students developed their self-esteem in the former. In the latter, students acquired a technician identity.

The processes that students have described in their PBL class have changed students' identity goals. Identity goals are identities that students desire or plan for, which then motivates them to create meanings that guide their behavior (Charmaz, 2011). It appears that the new identity goal that they acquired after their PBL experience is different from the goal identity with which they entered the PBL classroom. Although this does not necessarily imply that the change was all due to students' experience in project-based learning, it seems that the processes within PBL had a significant influence in shaping their new identity goals.

\section{Discussion and Implications}

This study attempts to identity the processes that students say they experienced in PBL and how these processes influenced their identities in a community college technician program. Identity theory based on symbolic interactionism (Blumer, 1986; Burke, 1991) is used as the analytic tool to explore student identities to obtain a more contextualized understanding of their behavior. This framework has allowed me to examine how students make sense of their experiences in a PBL classroom and how PBL 
impacts the way they act and shape their identities. Using of this framework, one of the constructs that has been identified in this study is a technician identity. As noted previously, identities are meanings that define what it means to be who one is in a role (Burke \& Tully, 1977; Goffman, 1959). The meaning of a technician identity in this study has become defined as being a student in a community college technician education who is technically knowledgeable and able to competently and with confidence apply that knowledge to solve a real-life or authentic technical problem, as would be expected of a technician in a job. Students who experienced PBL at SCC appear to have acquired this identity.

The findings here provides additional insights on what is special about learning, in a group, in an ill-structured project (Jonassen, 1997), as opposed to just learning individually or learning in a traditional classroom. Students' experience of PBL allows them to acquire a technician identity, which increases their confidence and lowers the barriers to access jobs that require this identity. For African Americans students and students from low socioeconomic backgrounds who are underrepresented in STEM, the acquisition of this identity is likely to provide an avenue to social mobility. Moreover, their experience provides them the self-esteem to continue their education and to pursue new ambitions, such as moving up the ladder in their organizations.

In summary, the success of participants indicates that PBL may be a promising practice that can help build the self-esteem of underrepresented students, including students of color and students from low socioeconomic backgrounds, first-generation 
students, students who may have had negative educational experiences in the past and people who have become unemployed. Moreover, it indicates that this process can cater to a diverse student body in terms of ages, work and educational background.

For these findings to be meaningful beyond this PBL program in one community college, further studies are needed. Studying other ill-structured problem-based learning programs with a focus on student identities would confirm or contradict the findings of this study and provide further data on the characteristics of ill-structured problem-based learning and how they influence student identities. However, without a comparison studies of well-structured problem-oriented learning it is not be possible to understand whether the change in student identities and self-efficacy is a unique characteristic of illstructured programs or whether components of well-structured programs also influence student identities in a similar manner. Without this knowledge, pedagogical or policy recommendations cannot be made.

\section{Acknowledgement}

This material is based upon work supported by the National Science Foundation under Grant No. DUE 1003589. Any opinions, findings, and conclusions or recommendations expressed in this material are those of the authors and do not necessarily reflect the views of the National Science Foundation.

\section{References}

Bailey, T., \& Morest, V. S. (2006). Defending the community college equity agenda (1st ed.). The Johns Hopkins University Press. 
Baxter, P., \& Jack, S. (2008). Qualitative case study methodology: Study design and implementation for novice researchers. The Qualitative Report, 13(4), 544-559.

Bell, S. (2010). Project-based learning for the 21 st century: Skills for the future. The Clearing House: A Journal of Educational Strategies, Issues and Ideas, 83, 3943. doi:10.1080/00098650903505415

Blumer, H. (1986). Symbolic interactionism: Perspective and method. University of California Press.

Bogdan, R., \& Biklen, S. K. (2006). Qualitative research for education: An introduction to theories and methods (5th ed.). Boston: Allyn \& Bacon.

Burke, P. J. (1991). Identity processes and social stress. American Sociological Association, 56(6), 836-849.

Burke, P. J., \& Reitzes, D. C. (1981). The link between identity and role performance. Social Psychology Quarterly, 44(2), 83-92.

Burke, P. J., \& Reitzes, D. C. (1991). An identity theory approach to commitment. Social Psychology Quarterly, 54(3), 239-251.

Burke, P. J., \& Stets, J. E. (1999). Trust and commitment through self-verification. Social Psychology Quarterly, 62(4), 347-366.

Burke, P. J., \& Tully, J. C. (1977). The measurement of role identity. Social Forces, $55(4), 881-897$.

Cast, A. D., \& Burke, P. J. (2002). A theory of self-esteem. Social Forces, 80(3), 10411068. 
Charmaz, K. (2011). Constructing grounded theory - A practical guide through qualitative analysis. Los Angeles, London, New Delhi, Singapore, Washington DC: Sage Publications.

Coyne, I. T. (1997). Sampling in qualitative research. Purposeful and theoretical sampling; merging or clear boundaries? Journal of Advanced Nursing, 26(3), 623-630. doi:10.1046/j.1365-2648.1997.t01-25-00999.x

Creswell, J. W. (2009). Research design: qualitative, quantitative, and mixed method approaches. Thousand Oaks, Calif.: Sage Publications.

Frank, M., Lavy, I., \& Elata, D. (2003). Implementing the project-based learning approach in an academic engineering course. International Journal of Technology and Design Education, 13, 273-288.

Gecas, V. (1982). The self-concept. Annual Review of Sociology, 8, 1-33.

Gee, J. P. (2000). Identity as an Analytic Lens for Research in Education. Review of Research in Education, 25, 99-125. doi:10.2307/1167322

Goffman, E. (1959). The presentation of the self in everyday life. New York: Anchor Books.

Graneheim, U. H., \& Lundman, B. (2004). Qualitative content analysis in nursing research: Concepts, procedures and measures to achieve trustworthiness. Nurse Education Today, 24, 105-112. 
Grant, M. (2011). Learning, beliefs, and products: Students' perspectives with projectbased learning. The Interdisciplinary Journal of Problem-Based Learning, 5(2), $37-69$.

Hakimzadeh, H., Adaikkalavan, R., \& Wolfer, J. (2011). CS0: A project based, active learning course. International Transaction Journal of Engineering, Management, \& Applied Sciences \& Technologies, 2(5), 493-506.

Helle, L., Tynjälä, P., \& Olkinuora, E. (2006). Project-Based Learning in Post-Secondary Education - Theory, Practice and Rubber Sling Shots. Higher Education, 51(2), 287-314. doi:10.1007/s10734-004-6386-5

Hoachlander, G., Sikora, A. C., \& Horn, L. (2003). Community College: Goals, academic preparation, and outcomes. Education Statistics Quarterly, 5(2), 121-128.

Jonassen, D. H. (1997). Instructional design models for well-structured and ill-Structured problem-solving learning outcomes. Educational Technology Research and Development, 45(1), 65-94.

Jonassen, D. H. (2000). Toward a design theory of problem solving. Educational Technology Research and Development, 48(4), 63-85.

Jonassen, D. H. (2012). Designing for decision making. Educational Technology Research Development, 60(2), 341-359.

Kaufman, P., \& Feldman, K. A. (2004). Forming identities in college. Research in Higher Education, 45(5), 463-495. 
Lehmann, M., Christensen, P., Du, X., \& Thrane, M. (2008). Problem-oriented and project-based learning (POPBL) as an innovative learning strategy for sustainable development in engineering education. European Journal of Engineering Education, 33(3), 283-295. doi:10.1080/03043790802088566

Malcom, L. E. (2013). Student diversity in community colleges - Examining trends and understanding the challenges. In J. S. Levin \& S. T. Kater (Eds.), Understanding community colleges (pp. 19-35). New York and London: Routledge.

Mayer, R. E., \& Wittrock, M. C. (1996). Problem-solving transfer. In D. C. Berliner \& R. C. Calfee (Eds.), Handbook of educational psychology (pp. 47-62). London, England: Prentice Hall International.

McDavid, J. C., \& Hawthorn, L. R. L. (2006). Program evaluation \& performance measurement: An introduction to practice. Sage Publications, Inc.

Meacham, J. A., \& Emont, N. C. (1989). The interpersonal basis of everyday problem solving. In J. D. Sinnott (Ed.), Everyday problem solving: Theory and applications. New York: Praeger.

National Center for Education Statistics. (2011). Table 205. Total fall enrollment in degree-granting institutions, by level and control of institution, attendance status, and sex of student: Selected years, 1970 through 2010. Digest of Education Statistics. Retrieved December 21, 2012, from http://nces.ed.gov/programs/digest/d11/tables/dt11_205.asp Noravian, A. (2013). Community college student perspectives on project-based learning. 
Savery, J. R. (2006). Overview of problem-based learning: Definitions and distinctions. Interdisciplinary Journal of Problem-Based Learning, 1(1), 9-20.

Silverman, D. (2011). Doing qualitative research: a practical handbook (Third edition.). Los Angeles: SAGE.

Spradley, J. P. (1979). The ethnographic interview. New York: Holt, Rinehart and Winston.

Stets, J. E., \& Burke, P. J. (2000). Identity theory and social identity theory. Social Psychology Quarterly, 63(3), 224-237.

Stryker, S. (2002). Chapter 11 - Traditional symbolic interactionism, role theory, and structural symbolic interactionism: The road to identity theory. In J. H. Turner (Ed.), Handbook of Sociological Theory (pp. 211-231). New York: Klumer Academic/Plenum Press. Retrieved from http://0www.springerlink.com.opac.sfsu.edu/content/j6852h0838745348/

Wenger, E. (2008). Community of practice. New York, NY: Cambridge University Press. Worthy, J. (2000). Conducting research on topics of student interest. Reading Teacher, 54(3), 298-299. 


\section{Appendix 1}

Table 1-List of participants and their backgrounds

\begin{tabular}{|c|c|c|}
\hline Participant & $\begin{array}{c}\text { Age/marital status/work } \\
\text { status/student status }\end{array}$ & About the participant \\
\hline John & $\begin{array}{l}\text { An African American senior } \\
\text { at a high school. } \\
\text { Taking classes in the } \\
\text { community college through a } \\
\text { special partnership program. }\end{array}$ & $\begin{array}{l}\text { John was from a school with a high } \\
\text { dropout rate. He was looking forward to } \\
\text { going to a } 4 \text { year university to do either } \\
\text { electrical engineering or computer } \\
\text { science. Tom described his experiences } \\
\text { in his current PBL class. }\end{array}$ \\
\hline Harry & $\begin{array}{l}\text { - Young married white male. } \\
\text { Enrolled in industrial } \\
\text { systems technology. } \\
\text { He was working fulltime as a } \\
\text { maintenance technician and } \\
\text { taught welding two nights a } \\
\text { week at another community } \\
\text { college. }\end{array}$ & $\begin{array}{l}\text { Harry had previously received a diploma } \\
\text { and an associate's degree in welding, a } \\
\text { diploma in air conditioning and heating. } \\
\text { He was thinking of applying to the local } \\
\text { year university to get his bachelor's in } \\
\text { industrial supervision online upon } \\
\text { completion of his associate's degree. He } \\
\text { saw education as a way to advance in his } \\
\text { job. Harry discussed the PBL class that } \\
\text { he had experienced at the beginning of } \\
\text { the industrial systems program. }\end{array}$ \\
\hline Mark & $\begin{array}{l}\text { - } 22 \text { year old white unmarried } \\
\text { male } \\
\text { Graduated with an } \\
\text { associate's degree in } \\
\text { industrial systems } \\
\text { technology. } \\
\text { - Was working full-time. }\end{array}$ & $\begin{array}{l}\text { Mark took time off after graduating from } \\
\text { high school at } 17 \text {. When he asked his } \\
\text { employer about the possibility of moving } \\
\text { up the ladder, they pointed him towards } \\
\text { college. He saw education as a path for } \\
\text { job advancement and success. Mark } \\
\text { discussed the PBL class that he had } \\
\text { experienced at the beginning of his } \\
\text { industrial systems technology. }\end{array}$ \\
\hline Peter & $\begin{array}{l}\text { - A white married male with } \\
\text { two young children. } \\
\text { - Graduated with machining } \\
\text { technologies and a } \\
\text { mechanical engineering } \\
\text { technology associate's } \\
\text { degrees. } \\
\text { Was working full-time. }\end{array}$ & $\begin{array}{l}\text { Peter had taken daytime, online, and } \\
\text { night-time classes while he supported } \\
\text { himself and his family through his } \\
\text { studies. His first degree took two years to } \\
\text { complete, while his second two-year } \\
\text { degree took five years because of his } \\
\text { personal and financial commitments. He } \\
\text { had been studying since } 2002 \text { ( } 9 \text { years). } \\
\text { He was thinking of continuing his } \\
\text { studies to obtain a bachelor's degree }\end{array}$ \\
\hline
\end{tabular}




\begin{tabular}{|c|c|c|}
\hline & & $\begin{array}{l}\text { from the local university which offered } \\
\text { online courses. He saw education as a } \\
\text { way to advance in his work. Peter } \\
\text { described the PBL program that he had } \\
\text { experienced at towards the end of this } \\
\text { study. }\end{array}$ \\
\hline Ben & $\begin{array}{l}\text { 47-year old divorced white } \\
\text { male. } \\
\text { Enrolled in the electronics } \\
\text { technology program. } \\
\text { - Was in a work-study } \\
\text { program. }\end{array}$ & $\begin{array}{l}\text { Ben had always been interested in } \\
\text { electronics, but had not been able to } \\
\text { receive training in this area, even in the } \\
\text { air force. He entered college after high } \\
\text { school, but dropped out. In this program } \\
\text { he said that he has learned a lot and he } \\
\text { believed that it would help him get a job. } \\
\text { Ben described the PBL class that he had } \\
\text { experienced in the beginning of this } \\
\text { electronics technology program. }\end{array}$ \\
\hline Don & $\begin{array}{l}\text { - "Sort of" married, African } \\
\text { American male, with two } \\
\text { young children. } \\
\text { - Enrolled in sustainability } \\
\text { technology. } \\
\text { - He was working as a } \\
\text { contract writer. }\end{array}$ & $\begin{array}{l}\text { Don was a veteran from the recent wars, } \\
\text { with some technical training. Upon } \\
\text { returning from the war, he had joined a } \\
\text { large banking institution. But after the } \\
\text { financial collapse he became } \\
\text { unemployed. He looked for a } \\
\text { sustainability program, which would } \\
\text { help him find something "he could build } \\
\text { on." He believed that this program was } \\
\text { the answer. Don described the PBL class } \\
\text { that he had experienced at the beginning } \\
\text { of this sustainability technology } \\
\text { program. }\end{array}$ \\
\hline Gary & $\begin{array}{l}\text { Married African American } \\
\text { male in his 50s with grown } \\
\text { children. } \\
\text { - Graduated with electronics } \\
\text { technology associate's } \\
\text { degree. } \\
\text { - He was working full time as } \\
\text { an electrician. }\end{array}$ & $\begin{array}{l}\text { Gary had come back to college in } 2007 \\
\text { after being laid off to get an electronics } \\
\text { technology degree. He attended college } \\
\text { full-time and worked part-time. } \\
\text { Previously he had attended university for } \\
\text { one year in } 1983 \text { after graduating from } \\
\text { high school, but he had dropped out after } \\
\text { the first year. Gary described the PBL } \\
\text { class that he had experienced at the } \\
\text { beginning of his electronics technology } \\
\text { programs. }\end{array}$ \\
\hline Tom & $\begin{array}{l}\text { - } 53 \text { year old African } \\
\text { American married male with }\end{array}$ & $\begin{array}{l}\text { Tom had previously held an associate's } \\
\text { degree in electronics technology. He had }\end{array}$ \\
\hline
\end{tabular}


grown children.

- Graduated with a degree in industrial management.

- Was working full-time as an electrician. returned to the community college to upgrade his skills after being laid off. He believed that his movement within the company he worked at was tied to his education. Tom described the PBL class that he had experienced in the beginning of his industrial management program. 


\section{Paper 3}

\section{How Do Well-Structured Problems Influence the Identities of Technology Students in Community College?}

Previous studies that have examined community college student experiences in

project-based learning with ill-structured problems in technology have revealed a boost in students' level of confidence (Noravian, 2013b) and the acquisition of technician identities (Noravian, 2013a). To investigate whether the change in student identities is a unique characteristic of projects with ill-structured problems or whether projects with well-structured problems can also influence student identities, this study examines the experiences of community college technology students who performed projects with well-structured problems. The findings could provide ideas for implementation and improvement of technology programs that support community college students' experiences in post-secondary education courses and their interest in STEM.

Problem-oriented learning, while always centered on a project, can be wellstructured or ill-structured. Mayer and Wittrock (1996) posited that problems range from vaguely defined with little structure to very routine and clearly defined. Well- and illstructured problems lie on a continuum, according to (Jonassen, 1997). Jonassen claims that it is the complexity of the problem, the clarity of the goals, the certainty of the criteria required to solve a problem, the prescriptiveness of the skills required, and the number of possible solutions or paths that determine where on the continuum a problem resides (1997). 
Ill-structured problems prompt students to use a multidisciplinary approach and may have multiple solutions or none at all (Jonassen, 2012). These types of problems prompt students to use their subjective understanding to approach the problem and to interpret the problem in context, facilitating social interaction (Meacham \& Emont, 1989). Moreover, in ill-structured approaches to learning teachers act as facilitators while students explore real-life problems (Savery, 2006). According to Grant (2011) and Worthy (2000), students should be self-directed and self-regulated, and the solution is often a product (Bell, 2010; Helle, Tynjälä, \& Olkinuora, 2006). In contrast, wellstructured problems have predictable solutions (Wood, 1983) that are found by applying the concepts or principles under study to a routine and constrained problem, much like end of textbook chapters or examinations (Jonassen, 2000).

Jonassen (1997) has noted that well-structured problems have limited usefulness because they are inconsistent with problems that students will encounter in their professional lives (Jonassen, 2000). Thus, he concluded that graduates who learned through well-structured problems did not develop the problem-solving skills that would help them function in professional contexts. He claimed that learners needed illstructured problem solving experience instead. The findings in the current study, however, suggest that well-structured problems can provide certain necessary on-the-job problem solving skills for technicians.

In prior studies, projects with ill-structured problems have been shown to impact students' professional identities (Noravian, 2013a). But projects that are ill structured 
require resources or training that instructors may not have. In this study, well-structured problems are used in laboratory projects to enhance the understanding of concepts learned in the classroom. This study examines whether projects that reside on the wellstructured end of the continuum offer the possibility of developing students' professional identities as technicians.

The data from first-year students who worked on projects with well-structured problems in a technology program at North West Community College (NWCC) - a pseudonym - is used to investigate whether and how their experiences affected their professional identities as technicians. Students in a community college technician education program who have acquired the technical knowledge and are able to apply that knowledge competently and with confidence to solve real-life problems, much like technicians would be expected to do in a job, have acquired a technician identity (Noravian, 2013a).

\section{Community College Students}

Students attend community colleges for a variety of reasons. The cost of attending a 2-year institution is well below that of a 4-year institution (Malcom, 2013). In addition, the close proximity to students' home also allows students to live at home while attending college, further reducing the financial burden (Malcom, 2013). Moreover, community colleges students are likely to have dependent children or families, be older than 24 , and have to balance work, family, and school (Bailey \& Morest, 2006). 
Community colleges are able to respond to industry needs by offering programs that prepare students for currently available jobs. At the same time, students needing to obtain employment quickly to support themselves and/or their families are able to obtain skills in a short time frame through access to industry jobs that require more than just a high school diploma (Malcom, 2013). Participants in this study who had families and who wanted to become financially independent were eager to obtain the skills needed to get a job. The program was designed to help them do that.

\section{Methodology}

The technology program at NWCC is a two-year program. In the first year, students learn fundamentals and basic low-tech skills. The learning takes place in courses that are designed as projects, often with both a theoretical classroom and a lab component.

\section{Data Collection}

I interviewed a total of six first-year students who had performed well-structured projects in the technology program at NWCC. The students were interviewed in pairs because that was the students' choice. The interview protocol used for this study included open-ended questions about the student experiences in various projects. Each interview took approximately 45 minutes and was conducted at NWCC.

The unit of study is the student experience within a project because projects capture the range of activities that instructors perceive is required to perform tasks and learn the course content. Students were asked to compare and contrast their experiences 
in two projects. This approach allows educators to understand whether, and if so, which aspects of students' experiences allowed them to acquire a technician identity (Noravian, 2013a).

\section{Participants}

The participants in this study were all first-year students who were asked to describe their experiences on two projects that they had performed and that provided data on six projects. These students were predominantly engaged in projects with wellstructured problems during the first year of the two-year technology program. The students were asked to select two projects that were different from each other based on the degree to which their instructor directed them as to what to do.

The students who volunteered to participate in this study were those who were present, available, and willing to participate at the time that I was present. Thus, the selection of participants was based on their willingness to participate and on their availability. To protect confidentiality, the names of the community college and the participants have been changed to pseudonyms.

Two of the six participants were students with families. Four of the participants live with their families while attending NWCC because they were either dual-enrolled in high school or had just graduated from high school.

The demographics of the participants reflected the program's and the county's demographics in that all were white and from working class backgrounds. The one participant who was female was the only female in the entire program. Some had entered 
the program from high school, while others entered the program after being laid off from work.

\section{Data Analysis}

To determine the level of structuredness of the six projects that participants described, the projects were compared to the characteristics of well- and ill-structured projects in the literature (Jonassen, 1997). In the following sections, I discuss each two projects that students described and compare and contrast their experiences.

\section{Findings}

\section{Boiler Project}

In the Boiler Project, students learned about boilers and how to maintain them. This project included a classroom component in which students learned from their instructor and a lab component in which students looked at the various physical parts of a boiler that they had learned about in their textbook. Thus, the lab portion provided the students the opportunity to see the principles that they had studied in their classroom and allowed them to do a limited set of tasks which they would be expected to do on the job with boilers. There were known outcomes for each action they performed. The instructor provided answers to questions that students had and they worked in small groups in the lab. From students' descriptions, the project met criteria for well-structured learning experience (Jonassen, 1997).

Both Ben and Harry believed that learning about boilers, even with a limited set of activities that they had in the lab, was important. They thought that if they were to get 
a job that required working with boilers, what they had learned in the lab would allow them to recognize boiler parts by sight and to perform specific tasks related to boilers.

Ben and Harry perceived the Boiler Project as useful, though not exciting or challenging. They explained that, "When we see this in industry, we'll know what it is and what we have to do with it." The process that students experienced was meaningful learning because it built the skills that they perceived they would need for becoming technicians. Thus, this project and their experience in it was seen as necessary for developing their technician identity (Noravian, 2013a).

\section{Programmable Logic Controller Project}

Like the Boiler Project, the Programmable Logic Controller Project also involved a theoretical component that was learned from classroom instruction and a problemsolving component that was performed in the lab. The students spent a specific period of time in their classroom learning about Programmable Logic Controllers with their instructor. The classroom instruction was then followed by working on a problem in the lab for students to augment their classroom learning. According to Ben and Harry, the instructor explicitly defined the lab instructions and the end goal. They were told which steps to follow to program a Programmable Logic Controller to do a specific task. Thus, even though both participants said that the instructor was more hands-off during the lab activity, the instructor had explicitly defined the tasks to be performed and the end goal to be accomplished. In solving the problem, students used specific principles that they had learned in the classroom. Furthermore, each step had a known outcome. Thus, the 
Programmable Logic Controller project also could be classified as a well-structured problem (Jonassen, 1997).

The students perceived that the purpose of the Programmable Logic Controller class was to get them to do specific tasks so that they could practice the skills that they had learned in the classroom, but they also believed that the level of these activities prepared them with skills needed for a job. They noted that when they made mistakes following the instructions given to them by their instructor, they had to do debugging to get the Programmable Logic Controller to do what was needed. They describe this process of debugging as challenging because they had to understand where they had made a mistake and how things really worked. Once they discovered the problem and fixed it to do what they wanted, it was, in their words, an "awesome" experience because it made them feel that they had "accomplished" something. This feeling of accomplishment was a result of their success in solving the problem, which arose as a result of their mistake.

\section{Comparing the boiler and the programmable logic controller projects.}

Ben and Harry compared their experiences in the boiler and the Programmable Logic Controller projects. Both projects were well structured, but students were affected by these projects in different ways. In the boiler project, students learned from looking at and touching the various things that they had learned about in the classroom. In the Programmable Logic Controller project, students learned from solving problems that enhanced their classroom learning and from making mistakes. The mistakes became the 
problems that they ultimately solved. In the boiler project, however, there was no opportunity for students to make mistakes, as they did not have to perform any hands-on work. This difference appears to have made the Programmable Logic Controller project more engaging.

Similar to the Boiler project, students saw the Programmable Logic Controller project as teaching them skills for a job. This perception is likely to have contributed to their technician identity (Noravian, 2013a). However, the students appeared much more excited about the Programmable Logic Controller than the Boiler project because they felt that the former provided them the kind of challenge that made them feel accomplished. Thus, although acquiring skills in both projects allows students to develop their technician identity, solving problems from mistakes that they made allowed the students to feel that they accomplished more than following instructions correctly and is likely to have influenced their self-esteem and ultimately their identities.

\section{Principles of Technology Project}

The Principles of Technology project was described by two other participants, Steve and Paul, as equivalent to a physics class for technology students. Similar to other first-year classes, this class included a classroom instruction component and a lab component. In the classroom, the students were taught concepts of physics and in the lab they worked on problems, such as measuring forces, angles, and momentum, that would demonstrate the concepts presented in the classroom. Both students agreed that in the lab they followed explicit steps to reach a specific objective. They did calculations to get the 
results that they were expected to get. Finally, the instructor signed off on what they had completed at the end of the lab sessions. Thus, the principles of technology project could be classified as a well-structured problem (Jonassen, 1997).

According to the interviews, the students felt that this class was less about learning and more about following a set of steps and getting from one point to the other. They perceived that the purpose of this lab was to follow instructions, get the results that they were expected to get, and get the instructor to sign off in it. As Steve explained, "We get our labs that are made by our instructor and then we are kind of just following a guideline." Paul added:

It's more depending on the actual letter grade. Have you done the work over time? It's not so much of have you learned the materials, but can you show that you've done the numbers. (Paul)

I interpret this to mean that the students had to meet a schedule and get the measurements that they needed. They felt that the explicit guidance helped them stay focused and the structure of the class helped them in planning for the work that needed to be done in the lab. From the interview of these two students, it is clear that they learned to do the work and presumably also learned some concepts. However, it was not clear that this type of learning had an effect on their technician identity because they did not relate what they were doing to what they might be expected to do in careers as technicians. 


\section{The Electrical systems Project}

The Electrical Systems Project also contained a classroom and a lab component. In the classroom, the instructor would discuss a type of electrical circuit, explain what the various components were, and discuss how each component worked. The students would then go to the lab, wire up the circuit, and test it to see if it worked the way it was expected to work. If not, the students would apply their troubleshooting skills to find and fix the problem so that the circuit would function as expected. Thus, the Electrical Systems project could be classified as a well-structured problem (Jonassen, 1997).

\section{Comparing principals of technology and electrical systems projects.}

Steve and Paul discussed two significant differences between the two projects that affected their perceptions: the level of independence and the grading method. In the Principals of Technology Project, the students followed specific steps to get their project done. They had to complete worksheets, labs, reports, and other required exercises. The instructor then needed to sign the lab work in order for the project to be considered finished. They also received assignments, quizzes, and weekly homework. Paul and Steve called this "guided learning." In contrast, in the Electrical Systems Project, the students were given a circuit drawing that they wired up, in their own time and at their own pace, and got it working. They did not have to fill out the various worksheets or do quizzes. The students called this "independent learning." According to Paul, "You don't have to do paperwork or write it up, but the more guided one you do have to do all that extra 
work. The independent one is just figuring it out." The students believe that these two types of learning taught them different responsibilities:

They're different kind of responsibilities because with the guided one, your responsibility is to make sure you keep up and with the independent one it's making sure you know the material and you're able to show the instructor that you know the material. (Paul)

Paul perceived that the Principals of Technology Project placed importance on keeping up whereas the Electrical Systems Project placed importance on learning the material. Another difference occurred in the way the students were graded in these two classes. In the Principals of Technology class, students were graded through assignments, quizzes, lab work, and homework. They had mid-term and final examinations. But in the Electrical Systems class, the students only had a final, in which they took a paper test. If they did not do well on the paper test, they were given another opportunity to demonstrate with their hands to their instructor that they knew their material:

There is a paper exam but if you do poorly on that, then you do well on hands-on, he'll [the instructor] kind of cancel it out because he wants to make sure we can do it with our hands because that's what the trade we're going to be going into would be like. (Paul)

This particular type of testing tells students that being able to do things with their hands is more important because that is what will be required of a technician in a workplace. This way of testing further defines what it means to be a technician for these students 
(Blumer, 1986; Burke, 1991). At this stage in the program the meaning of "hands on" may become part of their technician identity (Burke \& Reitzes, 1991; Noravian, 2013a), which is developing as a result of their Electrical Systems Project experience.

Although both students appreciated the flexibility offered by the "independent" learning in the Electrical Systems Project, there were differences between the preferences of the two students. Paul clearly preferred the independent learning:

I feel like I learn a little more with the independent because with the guided I'm just kind of mindlessly following instructions whereas with independent I'm kind of creating my own instructions which can help you remember things better. It's the difference between applying it and learning yourself and understanding it or just trying to keep up with the guidelines. (Paul).

For Paul the Electrical Systems Project offered a learning experience in which he developed his own meaning for the project (Blumer, 1986), but the Principals of Technology Project was an exercise which did not appear to have engaged him. Steve, on the other hand, preferred the guided learning: "I kind of prefer the more guided. I kind of like having all the practice that worksheets give you." For Steve, the more independent learning, although more flexible, was also a challenge; if he did not want to do what he had to do, he would fall behind. He felt that the more guided learning provided him the structure that he needed to get his work done.

Although the Principals of Technology and the Electrical Systems Projects were both well structured, they were implemented differently so that these two students' 
experiences in them were also different. The former is traditional in structure while the latter is more flexible. The Principals of Technology Project does not appear to have affected students' technician identity or self-esteem. On the other hand, the level of independence offered in the Electrical Systems Project allowed students to feel in charge of their own learning and the assessment of their performance was similar to how they would be assessed on the job. Thus, the Electrical Systems Project had more of an influence on their technician identities (Noravian, 2013a). Moreover, the Electrical Systems Project is similar to the Programmable Logic Controller project in that students learn from solving the problems that occurred as a result of mistakes they made. Thus, the Electrical Systems Project is also likely to have influenced their self-esteem as students and as technicians.

Students' preferences for the structure of the projects differed. Although both students were first-year students who had entered NWCC from high school, Paul said he preferred flexibility while Steve said he appreciated flexibility but preferred learning the traditional, structured way he was used to in high school. In some ways, the lack of flexibility of the Principals of Technology Project provided him a level of comfort, familiarity, and certainty.

\section{Electronics Project}

The electronics project, much like other projects had a classroom and a lab component. Students learned about the basic principles associated with electronics parts, 
such as transistors, in the classroom from their instructor, but in the lab they had to figure things out how to, for instance, test such components on their own.

John and Sue explained that in one lab session, they were asked to do research and collect information from the Internet on various kinds of transistors, learn about characteristics of transistors, and learn how to test them. In the next lab session the students had to then actually test the transistors that they were given to see if the parts were functioning or if they were damaged. What this meant was that although students had learned in the classroom what transistors looked like and how they functioned, they had to learn certain facts about these components on their own in the first lab session and apply what they had learned to solve the problem of separating working transistors from damaged ones in the second lab session. Moreover, they had to know how to use a multimeter to test the transistor.

The problem they described presented a different level of challenge for John than for Sue. John had collected sufficient data and the right kind of data in the first lab session so that he had enough information to test the transistors in the second lab session. He knew he had to do this. On the other hand, Sue found applying the data she had collected to testing the transistors a challenge for a couple of reasons. First, she had missed the classes in which the students had learned how to use multi-meters. Thus, she was not comfortable with using the multi-meters to do measurements on the components. Second, the lack of explicit directions made this task much more difficult for her: 
For example, with transistors there are three prongs out of the transistors and you're using your meter attached to the different prongs. You get different readings and if it's shorted out it'll give a different type of reading. If it's blown, it will give a different type of reading. It's trying to take the different types of readings and understanding what it means and when I did it, I didn't quite get all of the different types of what the meter reads to what it means with the transistor....We didn't know what we're actually going to be having to test for, so we didn't actually get, some of us didn't get all the information that we actually needed. (Sue)

It seems that Sue was not sure what the readings on the multi-meter meant, partially due to her lack of comfort with the multi-meter and her uncertainty in interpreting the results with it. But she also had not collected sufficient data or the right kind of data in the first lab. The inadequate data collection may have been partially due to lack of explicit directions from the instructor, which made the process ambiguous for her. This ambiguity makes this problem less well-structured along the structuredness continuum (Jonassen, 1997).

The difference in how Sue and John experienced this project may be due to their prior work experience. John had worked for many years in the technology industry whereas Sue had no previous work experience and had just entered NWCC after taking her GED. It seemed that John's prior work experience in a technology company enabled him to feel more comfortable with this type of learning. 
According to John, testing transistors was the kind of task that a technician would be required to perform in the workplace. Thus, success with this type of problem likely contributed to developing John's technician identity (Noravian, 2013a) but is not likely to have the same affect on Sue. This was a negative experience for Sue. She was left feeling that she and other students like her had a lot to learn and that they were not clear about what they had learned whereas John felt that he had managed to cope well. Competence, also called efficacy-based self-esteem, refers to the degree to which people see themselves as capable and efficacious (Cast \& Burke, 2002). This experience is not likely to contribute to Sue's feeling of competence, but it might for John who achieved his goal.

John, because of his working background in the technology industry found the individual research aspect of the electronics project to be something that is expected of people on the job, but he also saw that even in a workplace, individuals do get an opportunity to get help from others when needed. In this project, the students were encouraged to work on their own:

Well I don't mind the research on my own ...Sometimes you'll have a manual that tells you step by step what to do and sometimes you don't have that...but I know on the job sometimes you do have to do that kind of search for components. So sometimes you have to learn how to do that. That was useful but generally you can also talk to the guy at the desk next to you and ask some questions too. (John) John's industry experience had an effect on how he interpreted the social aspects of this project in the lab. 
It seems that for this type of learning to be effective and help develop student efficacy-based self-esteem (Cast \& Burke, 2002) a certain level of explicit initial direction may help students become familiar with the process. In addition, content and/or tool knowledge is important. Otherwise students like Sue would feel inadequate in both her knowledge and processes. Thus, for first year students who may not have previous experience in this type of learning or problem solving, unless they develop more experience with the tools they use or with the content material, this experience may be a negative one and likely to diminish their feelings of competence.

\section{Pneumatics Project}

Like other projects, the pneumatics project had a classroom instruction and a lab component. Students learned various pneumatics concepts in the classroom and applied them to solve a problem in the lab to enhance their understanding of the material.

According to the students, they experienced the pneumatics projects in the beginning of the term differently from how they experienced them as the term progressed. In the beginning, they were given a circuit to build in the lab to perform a specific function. The steps for building a given circuit, testing it, and making sure that it functioned as specified were given to them explicitly by the instructor. However, the students were required to figure out the debugging of the circuit by themselves, which helped them develop debugging skills. There were many possible reasons for why circuits may not have worked, such as incorrect wiring or broken wires. Thus, the debugging task was ambiguous because the problem was unpredictable, unlike the 
description of a well-structured project (Jonassen, 1997). It was possible that what the student discovered during hands-on problem solving had nothing to do with the theory they learned in the classroom. The debugging portion also required intense interaction with either a project partner (if they were working in a group) or with a classmate who was not part of the project. Interacting with others to get help did not necessarily mean that they got their problems solved easily as these problems were always different and may have been hard to find and resolve. However, these interactions helped the students realize that even more experienced, such as the teaching assistant, did not necessarily have the solutions to the problems they were experiencing and that the students were having difficulty because they were solving a difficult problem. In this respect, the pneumatics project was like Programmable Logic Controller and Electrical Systems projects in which the students followed explicit instructions and in the process had the opportunity to make mistakes and learn from their mistakes. Thus, the pneumatics project was a well-structured problem (Jonassen, 1997), at least in the beginning of the term.

The project evolved from well-structured to less well-structured as the semester progressed. Sue describes the progression: "As the term goes on [the instructor] becomes slightly more vague because by that time we're supposed to know how to take one of these very vague description and create what it's supposed to do." At the end of the term, the end goal was still determined by the instructor, but the solution was determined by the students. The solution involved using concepts, rules and materials that they were learning in the classroom and was bound by the parts that were available on the 
pneumatics trainer. However, the solution path was "vague" according to Sue. Thus, while the project was well-structured (Jonassen, 1997) in many ways, it had a component, the solution path, that had the characteristics of an ill-structured project (Jonassen, 1997). Stating this another way, an ill-structured component was introduced within a wellstructured project as students learned more content and became more familiar with the processes required to solve pneumatics problems. Thus, in contrast with the electronics project, the pneumatics project helped students develop knowledge and experience before having to tackle more technically sophisticated and ill-structured problems. Sue found the process of slowly moving from the well- to ill-structured side of the continuum as helpful:

For me it makes more sense. I mean, having more guided instructions in the beginning, it allows us to understand it better...In the beginning he gave us really detailed instructions because we didn't know how to do it, but as it got farther into the program, he gave us less instructions because he expected us to know how to do it by then. But the circuits we were creating were very complex.

Sue's reaction in the pneumatics project was in sharp contrast to her reaction to the electronics project. She felt that she had learned to "create very complex circuits" in the pneumatics project, whereas in electronics project she was left feeling that she had not learned what she was meant to learn adequately. Thus, the approach of building up students' knowledge base in both content and process of dealing with complex problems appears to be an effective approach to learning. Moreover, I interpret Sue's use of the 
term "create" when she refers to circuits as meaning that she perceived these circuits to be products of her own imagination and knowledge. This perception may indicate that she had achieved a high level of efficacy-based self-esteem (Cast \& Burke, 2002) as a result of her experience in the pneumatics project.

\section{Comparing the electronics and the pneumatics projects.}

According to Sue, who compared the pneumatics with the electronics projects, she preferred the more guided instruction: "Having more guided instructions in the beginning, it allows us to understand it better." According to John, the well-structured aspect of the project allowed students to learn effective ways or patterns for learning and doing new things. The structuredness of the pneumatics project changed as the term progressed. The project initially began as a well-structured problem, but as the term progressed, the structure of the problem changed to include a less well-structured component within a well-structured problem. The well-structured portion may have been used as a scaffold to build students' confidence, experience, and knowledge before exposing them to the less well-structured problems at the end of the term. This approach allowed students to learn a different way of thinking and a process for implementing a solution within given set of constraints and prepared them for dealing with higher levels of ambiguity.

\section{Discussion and Implications}

This study examines whether projects with well-structured problems influence technician identities of first year community college students in a technology program. 
The findings indicate that students perceived that some of the well-structured tasks that they performed helped build the skills that they needed to become technicians or were the kinds of activities that they would be required to perform as technicians. It is this perception that helped them connect their learning to becoming a technician (Noravian, 2013a). Developing a professional identity in community college for a job that requires an associate's degree may help students overcome the anxieties associated with being first in their family to seek such jobs.

It is the perception that what they learn leads to acquiring necessary job skills that connects student learning directly to becoming technicians. This perception implies that technology programs with well-structured problem-solving projects could help develop students' professional identities if they were designed to identify the learning-to-job connections for students. Moreover, knowing that what they learn is directly connected to on-the-job skills could motivate community college students to enter such programs and persevere, particularly if they have to make financial sacrifices to be in such a program. Lastly, the connection between what students learn and job skills indicates that wellstructured projects could be perceived as consistent with problems that students will need to solve in their jobs. This finding appears to contradict Jonassen's (2000) claim that well-structured problems do not provide adequate preparation for graduates to function in professional contexts.

As the data shows, well-structured problems become more engaging and make an impression on the students if they are given the space to make mistakes. Making a 
mistake and solving the problem in a well-structured project allows the students to feel that they have accomplished something beyond just following instructions and getting the right answers. It seems that students might learn concepts that they are required to learn, with or without the challenge of learning from mistakes, but the mistakes they make allow them to learn concepts beyond what is taught in the classroom. The challenge of finding and fixing a problem had a positive impact on students' self-esteem in an environment where they do not have to face negative consequences for making mistakes.

Well-structured projects with high levels of prescriptiveness and low levels of flexibility may have the least impact on students' technician identities and learning experience. On the other hand, well-structured projects with some level of flexibility and low levels of prescriptiveness are perceived by students as projects that place importance on independent learning. This combination allows students to see themselves as being more capable than just following instructions and provides a more meaningful learning experience. Moreover, if such projects assess students' performance similarly to how their performance will be assessed on the job, this experience might help them further develop a technician identity.

Finally, negative experiences in projects that are less well-structured could have a concomitant negative impact on students' feelings of competence. The experience described by one of the participants in the electronics project indicates that students could have a negative experience if they do not have the required content knowledge and/or familiarity with problems that are ambiguous and are technically sophisticated. The 
student was left feeling that she and other students like her did not learn what they were supposed to learn. Thus, for students to have a learning experience which develops their self-esteem, it is important that they have the right level of technical knowledge to tackle a sophisticated technical problem which requires them to deal with ambiguity. Perhaps projects that begin as well-structured and become less well-structured, as described in the pneumatics project, could be more effective in developing students with no prior experience to successfully tackle technically sophisticated and more ill-structured projects (Jonassen, 1997). This indicates that instructors should not choose between welland ill- structured problems. Rather, curriculum design should focus on scaffolding from very well-structured to less well-structured and then to ill-structured problems.

\section{Acknowledgement}

This material is based upon work supported by the National Science Foundation under Grant No. DUE 1003589. Any opinions, findings, and conclusions or recommendations expressed in this material are those of the authors and do not necessarily reflect the views of the National Science Foundation.

\section{References}

Bailey, T., \& Morest, V. S. (2006). Defending the community college equity agenda (1st ed.). The Johns Hopkins University Press.

Bell, S. (2010). Project-based learning for the 21st century: Skills for the future. The Clearing House: A Journal of Educational Strategies, Issues and Ideas, 83, 3943. doi:10.1080/00098650903505415 
Blumer, H. (1986). Symbolic interactionism: Perspective and method. University of California Press.

Burke, P. J. (1991). Identity processes and social stress. American Sociological Association, 56(6), 836-849.

Burke, P. J., \& Reitzes, D. C. (1991). An identity theory approach to commitment. Social Psychology Quarterly, 54(3), 239-251.

Cast, A. D., \& Burke, P. J. (2002). A theory of self-esteem. Social Forces, 80(3), 10411068 .

Grant, M. (2011). Learning, beliefs, and products: Students' perspectives with projectbased learning. The Interdisciplinary Journal of Problem-Based Learning, 5(2), $37-69$.

Helle, L., Tynjälä, P., \& Olkinuora, E. (2006). Project-Based Learning in Post-Secondary Education - Theory, Practice and Rubber Sling Shots. Higher Education, 51(2), 287-314. doi:10.1007/s10734-004-6386-5

Jonassen, D. H. (1997). Instructional design models for well-structured and ill-Structured problem-solving learning outcomes. Educational Technology Research and Development, 45(1), 65-94.

Jonassen, D. H. (2000). Toward a design theory of problem solving. Educational Technology Research and Development, 48(4), 63-85.

Jonassen, D. H. (2012). Designing for decision making. Educational Technology Research Development, 60(2), 341-359. 
Malcom, L. E. (2013). Student diversity in community colleges - Examining trends and understanding the challenges. In J. S. Levin \& S. T. Kater (Eds.), Understanding community colleges (pp. 19-35). New York and London: Routledge.

Mayer, R. E., \& Wittrock, M. C. (1996). Problem-solving transfer. In D. C. Berliner \& R. C. Calfee (Eds.), Handbook of educational psychology (pp. 47-62). London, England: Prentice Hall International.

Meacham, J. A., \& Emont, N. C. (1989). The interpersonal basis of everyday problem solving. In J. D. Sinnott (Ed.), Everyday problem solving: Theory and applications. New York: Praeger.

Noravian, A. (2013a). Acquiring professional identities in project-based learning in a community college. Manuscript submitted for publication.

Noravian, A. (2013b). Community college student perspectives on project-based learning. Manuscript submitted for publication.

Savery, J. R. (2006). Overview of problem-based learning: Definitions and distinctions. Interdisciplinary Journal of Problem-Based Learning, I(1), 9-20.

Worthy, J. (2000). Conducting research on topics of student interest. Reading Teacher, $54(3), 298-299$. 


\section{Appendix A}

\section{JOURNAL OF ENGINEERING EDUCATION}

The research journal for engineering education

Published by the American Society for Engineering Education

Dear Ms. Noravian:

I assigned your manuscript, "Community College Student Perspectives on Project-Based Learning," manuscript number JEE-3120, to an associate editor. Following the review protocol for the Journal of Engineering Education, the associate editor thoughtfully evaluated the manuscript and decided not to send the manuscript out for review. Based on the evaluation by the associate editor, as well as my own reading, I believe the manuscript is not yet suitable for publication in the Journal of Engineering Education. If you do decide to submit a new manuscript, I would encourage you to consider the questions and issues raised by the associate editor. I have added my own comments at the end of this message.

Again, thank you for allowing the Journal of Engineering Education the opportunity to consider your manuscript. I hope that these comments are of value to you.

Sincerely,

Michael C. Loui

Editor, Journal of Engineering Education

Professor of Electrical and Computer Engineering

University of Illinois at Urbana-Champaign

loui@illinois.edu

Comments from Associate Editor to Author

1. The literature review is very brief, especially on PBL. The review on PBL does not illustrate the depth of PBL, where it can range from being a philosophy (as embraced by AAU, which is briefly cited in the literature review), to being a teaching and learning approach which is one of the active learning techniques. Which model of PBL embraced and used is also not clearly stated.

2. The qualitative method used looks more like phenomenology rather than Symbolic Instruction

(http://instructionall .calstatela.edu/bberk/Soc414/W\%20Symbolic\%20Interaction\%20D4 $\% 5 \mathrm{~B} 1 \% 5 \mathrm{D} . \mathrm{htm})$, which should be analyzed at 3 levels: social interaction, individual actions and subjective processes. What is mostly discussed is just the result, rather than 
how the data is analyzed to reach the result. Showing how the data are analyzed is very important when using qualitative analysis - otherwise, it is not clear how the authors arrive at the result.

3. The conclusion and implications are also brief, and do not provide much insight for educators.

Comments from Editor to Author

Although the literature on PBL is extensive, you have chosen an understudied setting for PBL, community colleges. Is there any theoretical reason why the learning outcomes and student experiences for PBL in community college should differ from those of low-SES students in four-year institutions?

The manuscript omits many standard features of qualitative research studies, especially studies published in JEE; see http://onlinelibrary.wiley.com/iournal/10.1002/\%28ISSN\%2921689830/homepage/ForAuthors.html and articles published in JEE in recent years. The manuscript lacks an explicit statement of research questions. The manuscript does not state the researcher's positionality and epistemological commitment. The manuscript does not justify the selection of participants: why are their experiences particularly information-rich? The manuscript does not explain the methods used to achieve trustworthiness (credibility, dependability, transferability). The analysis of the data tends to summarize the themes rather than to interpret the themes in light of a theoretical or conceptual framework. The manuscript does not discuss alternative explanations and rival conclusions. The discussion section does not relate the findings to previous work on PBL. Most important, the manuscript does not make the case for why the findings represent a significant contribution to building knowledge about engineering education, with new implications for future practice or research. 


\section{Appendix B}

\section{MS \#1431 - Interdisciplinary Journal of Problem-based Learning Michael M Grant [editor-ijpbl-1431-736313@docs.lib.purdue.edu] Sent:Tuesday, October 22, 2013 11:04 AM \\ To: Armineh Noravian}

Cc: The Authors [authors-ijpbl-1431@docs.lib.purdue.edu]; The Editors [editors-ijpbl-1431@docs.lib.purdue.edu]

Dear Armineh Noravian

The reviews of your paper entitled "Acquiring Professional Identities in Project-Based Learning in a Community College" have been returned. Following the advice from two reviewers and my own editor's review, we will not accept the manuscript for publication. The reviews provide quite extensive suggestions for continuing to improve the manuscript, which should be helpful to you if you decide to revise and submit it elsewhere.

In particular, the first reviewer has marked up a copy of your manuscript with a number of comments and questions that I believe are essential to improving your work. I hope this is helpful. The reviewers were similar in their comments and concerns. They noted the lack of an expiicit research question(s), insufficient details in the method, and the unsupported findings that do not explain or support the connections between the PBL activities and student outcomes as elements that must be addressed. Reviews are available at the following page: http://docs.lib.purdue.edu/cgi/preview.cgi?article=1431\&context=ijpbl Thank you for your submission and we hope you'll consider IJPBL in the future for your work.

Michael M Grant

Editor

Interdisciplinary Journal of Problem-based Learning 